\title{
Changes in dissolved iron deposition to the oceans driven by human activity: a 3-D global modelling study
}

\author{
S. Myriokefalitakis ${ }^{1}$, N. Daskalakis ${ }^{1,2}$, N. Mihalopoulos ${ }^{1,3}$, A. R. Baker ${ }^{4}$, A. Nenes ${ }^{2,5,6}$, and M. Kanakidou ${ }^{1}$ \\ ${ }^{1}$ Environmental Chemical Processes Laboratory, Department of Chemistry, University of Crete, \\ P.O. Box 2208, 70013 Heraklion, Greece \\ ${ }^{2}$ Institute of Chemical Engineering Sciences (ICE-HT), FORTH, Patras, Greece \\ ${ }^{3}$ Institute for Environmental Research and Sustainable Development, National Observatory of Athens, \\ Athens, Greece \\ ${ }^{4}$ School of Environmental Sciences, University of East Anglia, Norwich, NR4 7TJ, UK \\ ${ }^{5}$ School of Earth and Atmospheric Sciences, Georgia Institute of Technology, 311 Ferst Drive, \\ Atlanta, GA 30332-0100, USA \\ ${ }^{6}$ School of Chemical and Biomolecular Engineering, Georgia Institute of Technology, 311 Ferst Drive, \\ Atlanta, GA 30332-0100, USA
}

Correspondence to: S. Myriokefalitakis (stelios@uoc.gr) and M. Kanakidou (mariak@uoc.gr)

Received: 31 December 2014 - Published in Biogeosciences Discuss.: 02 March 2015

Revised: 31 May 2015 - Accepted: 09 June 2015 - Published: 02 July 2015

\begin{abstract}
The global atmospheric iron (Fe) cycle is parameterized in the global 3-D chemical transport model TM4-ECPL to simulate the proton- and the organic ligandpromoted mineral-Fe dissolution as well as the aqueousphase photochemical reactions between the oxidative states of Fe (III/II). Primary emissions of total (TFe) and dissolved (DFe) Fe associated with dust and combustion processes are also taken into account, with TFe mineral emissions calculated to amount to $\sim 35 \mathrm{Tg}-\mathrm{Fe} \mathrm{yr}^{-1}$ and $\mathrm{TFe}$ emissions from combustion sources of $\sim 2 \mathrm{Tg}_{-} \mathrm{Fe}_{\mathrm{yr}}{ }^{-1}$. The model reasonably simulates the available Fe observations, supporting the reliability of the results of this study. Proton- and organic ligand-promoted Fe dissolution in present-day TM4ECPL simulations is calculated to be $\sim 0.175 \mathrm{Tg}_{-} \mathrm{Fe} \mathrm{yr}^{-1}$, approximately half of the calculated total primary DFe emissions from mineral and combustion sources in the model $\left(\sim 0.322 \mathrm{Tg}^{-\mathrm{Fe}_{\mathrm{yr}}}{ }^{-1}\right)$. The atmospheric burden of $\mathrm{DFe}$ is calculated to be $\sim 0.024 \mathrm{Tg}-\mathrm{Fe}$. DFe deposition presents strong spatial and temporal variability with an annual flux of $\sim 0.496 \mathrm{Tg}^{-F e ~} \mathrm{yr}^{-1}$, from which about $40 \%(\sim 0.191 \mathrm{Tg}-$ $\mathrm{Fe}_{\mathrm{yr}} \mathrm{C}^{-1}$ ) is deposited over the ocean. The impact of air quality on Fe deposition is studied by performing sensitivity simulations using preindustrial (year 1850), present (year 2008) and future (year 2100) emission scenarios. These simulations
\end{abstract}

indicate that about a 3 times increase in Fe dissolution may have occurred in the past 150 years due to increasing anthropogenic emissions and thus atmospheric acidity. Air-quality regulations of anthropogenic emissions are projected to decrease atmospheric acidity in the near future, reducing to about half the dust-Fe dissolution relative to the present day. The organic ligand contribution to Fe dissolution shows an inverse relationship to the atmospheric acidity, thus its importance has decreased since the preindustrial period but is projected to increase in the future. The calculated changes also show that the atmospheric DFe supply to the globe has more than doubled since the preindustrial period due to 8fold increases in the primary non-dust emissions and about a 3-fold increase in the dust-Fe dissolution flux. However, in the future the DFe deposition flux is expected to decrease (by about $25 \%$ ) due to reductions in the primary non-dust emissions (about 15\%) and in the dust-Fe dissolution flux (about $55 \%$ ). The present level of atmospheric deposition of DFe over the global ocean is calculated to be about 3 times higher than for 1850 emissions, and about a $30 \%$ decrease is projected for 2100 emissions. These changes are expected to impact most on the high-nutrient-low-chlorophyll oceanic regions. 


\section{Introduction}

Atmospheric deposition of trace constituents, both of natural and anthropogenic origin, can act as a nutrient source into the open ocean and therefore can affect marine ecosystem functioning and subsequently the exchanges of $\mathrm{CO}_{2}$ between the atmosphere and the global ocean (Duce et al., 2008). In surface waters, the phytoplankton photosynthetic activity uses $\mathrm{CO}_{2}$ and nutrients to produce biomass and is responsible for nearly half of annual $\mathrm{CO}_{2}$ exchange with the deep ocean that contains $\sim 85 \%$ of Earth's mobile carbon (Shao et al., 2011). This is the so-called "biological pump", where the deeper the carbon sinks, the longer it will be removed from the atmosphere (Falkowski et al., 2000). The net result of the biological pump is a continual atmospheric carbon transfer to the deep ocean. Aeolian dust deposition, calculated to be $\sim 1257 \mathrm{Tg} \mathrm{yr}^{-1}$ (median of 15 global models by Huneeus et al., 2011), contains $\sim 3.5 \%$ iron (Fe) on average, and it is the most significant external supply of $\mathrm{Fe}$ (as a micronutrient) in surface waters (Taylor and McLennan, 1985; Mahowald et al., 2005, 2009). Fe scarcity limits phytoplankton productivity in high-nutrient-low-chlorophyll (HNLC) regions (i.e. the Southern Ocean, the eastern equatorial and the subarctic Pacific; Boyd et al., 2005) and thus primary productivity in large portions of the global ocean, significantly affecting the biological carbon export on a global scale (Maher et al., 2010). The correlation between Fe supply and atmospheric $\mathrm{CO}_{2}$-trapping to the ocean forms the so-called "Iron Hypothesis" (Martin and Fitzwater, 1988) that initiated significant scientific debate on the potential use of Fe to fertilize the global ocean (i.e. geoengineering) and consequently increase $\mathrm{CO}_{2}$ storage in the ocean (e.g. Moore and Doney, 2007).

The bioavailable form of $\mathrm{Fe}$ that is acquired by phytoplankton is associated with the soluble fraction of Fe, which is measured experimentally as the fraction filterable through 0.2-0.45 $\mu \mathrm{m}$ filters (Kraemer, 2004). Aerosols are emitted or formed, transported and deliquesce in the atmosphere (Raes et al., 2000). Processes that occur in the water associated with aerosols can change aerosol properties. There is experimental evidence that atmospheric acidity is increasing dust solubility (e.g. Nenes et al., 2011) and that present-day atmospheric acidity is mainly driven by air pollution (Seinfeld and Pandis, 1998 and references therein). Although the fraction of soluble Fe in soil is low $(\sim 0.1 \%$; Mahowald et al., 2009 and references therein); atmospheric chemical processes are responsible for $\mathrm{Fe}$ conversion to more soluble forms (Mahowald et al., 2009), and thus bioavailable form for the ocean biota. Dust coating by acid-soluble materials (e.g. nitrates, sulfates) also alters the global pattern of Fe deposition (Fan et al., 2004).

Significant scientific effort has been made to understand the impact of anthropogenically driven atmospheric acidity on dust and parameterize it in global models. To study the aforementioned changes in dust-Fe solubility driven by human activities, atmospheric models need to account for both (i) the composition of the Fe source and (ii) the atmospheric aging of dust. However, the atmospheric chemical aging of dust with respect to dissolved/bioavailable Fe (hereafter $\mathrm{DFe}$ ) production is parameterized in chemistry transport models (CTMs) in different ways. In the modelling study of Meskhidze et al. (2005), hematite $\left(\mathrm{Fe}_{2} \mathrm{O}_{3}\right)$ was considered as the only Fe-containing mineral in dust (5\% mass fraction of hematite in dust) and the proton-promoted $\mathrm{Fe}$ dissolution was described using the empirical parameterization developed by Lasaga et al. (1994). That study simulated the production of DFe in the ferric oxidation state (Fe(III)) but did not account for any photochemical cycling between $\mathrm{Fe}(\mathrm{III})$ and $\mathrm{Fe}(\mathrm{II})$. Luo et al. (2008), using the same approximation, considered the formation of DFe in the ferrous form (Fe(II)) during Fe-containing mineral dissolution. In support of the protonpromoted $\mathrm{Fe}$ dissolution hypothesis, a positive correlation of Fe solubility (hereafter SFe; $\mathrm{SFe}=100 \times \mathrm{DFe} / \mathrm{TFe}$ ) and sulfur emissions has been observed for acidic atmospheric samples collected at urban sites (Oakes et al., 2012). The simulations by Solmon et al. (2009) suggest that the doubling of sulfur emissions can increase the proton-promoted dissolution and deposition of dissolved Fe to the remote Pacific Ocean by $\sim 13 \%$.

$\mathrm{Fe}$ dissolution from minerals under acidic conditions occurs on different timescales; from hours to weeks depending on the size and the type of the Fe-containing mineral (Shi et al., 2011a). However, the buffering capacity of minerals, like $\mathrm{CaCO}_{3}$ and $\mathrm{MgCO}_{3}$, which reside in coarse dust particles, may regulate mineral-Fe proton-promoted dissolution, contributing, among others, together with combustion emissions of DFe on fine particles and atmospheric transport, to an observed inverse relationship between $\mathrm{SFe}$ and particle size (Ito and Feng, 2010). A recent CTM study (Ito and Xu, 2014) simulated the present-day SFe over the Northern Hemisphere oceans reasonably well, and calculated the proton-promoted dissolution of $\mathrm{Fe}$ in the year 2100, considering three pools of Fe-containing minerals depending on their timescale of potential for Fe dissolution, based on the findings of Shi et al. (2011b; 2012).

Laboratory studies have also shown the occurrence of photoinduced reductive $\mathrm{Fe}$ dissolution under rather acidic conditions (e.g. $\mathrm{pH}<4$ ), suggesting a steady-state $\mathrm{Fe}(\mathrm{II})$ production during exposure of dust to solar radiation and thus increased daytime dissolution rate of hematite compared to standard kinetics (Zhu et al., 1993; Jickells and Spokes, 2001 and references therein). However, the dust-Fe dissolution through photoreduction only has a limited impact $(<1 \%)$ on the DFe concentration (Zhu et al., 1993). Moreover, experimental data also support that both inorganic (e.g. sulfuric and nitric acid) and organic (e.g. oxalic and acetic acid) acids can increase Fe dissolution (Paris et al., 2011; Paris and Desboeufs, 2013). Laboratory investigations (Chen and Grassian, 2013) also indicate that the relative capacity of oxalic acid in acidic solution $(\mathrm{pH}=2)$ is by far the most important for Fe dissolution in dust and combustion aerosols com- 
pared to sulfuric acid due, to the formation of mononuclear bidentate ligand with surface $\mathrm{Fe}$, in contrast to the weaker complexes formed from $\mathrm{HSO}_{4}^{-}$and $\mathrm{SO}_{4}^{2-}$.

Oxalic acid/oxalate (hereafter OXL) is globally the most abundant dicarboxylic acid, formed via chemical oxidation of both biogenic and anthropogenic gas-phase precursors in the aqueous phase of aerosols and cloud droplets (e.g. Carlton et al., 2007; Lim et al., 2010). Johnson and Meskindze (2013) calculated that the ligand (OXL) -promoted $\mathrm{Fe}$ dissolution and $\mathrm{Fe}(\mathrm{II}) / \mathrm{Fe}(\mathrm{III})$ redox cycling of $\mathrm{Fe}$ content of mineral dust in both aerosol and cloud water increased total annual calculated DFe deposition to global oceanic regions by $\sim 75 \%$, compared to only proton-promoted $\mathrm{Fe}$ dissolution simulations. However, the aforementioned study used sulfate aerosol as a proxy for the occurrence of OXL and took three Fe-containing dust minerals (i.e. goethite, hematite and illite) into account, as studied by Paris et al. (2011). A recent modelling study by Ito (2015), published after the submission of the present work, focusing on the atmospheric processing of Fe-containing combustion aerosols by photochemical reactions with inorganic and organic acids, indicates that ligand (OXL)-promoted Fe dissolution more than doubles the calculated DFe deposition from combustion sources over certain regions of the global ocean.

Besides proton- and ligand-promoted mineral-Fe dissolution, primary emissions of $\mathrm{Fe}$, especially from combustion processes, can lead to an increase in the SFe fraction. Mineral-Fe represents $\sim 95 \%$ of the global atmospheric TFe source, with combustion $\mathrm{Fe}$ sources responsible for the remaining 5\% (Luo et al., 2008; Mahowald et al., 2009). Luo et al. (2008) accounted for both soluble and insoluble forms of Fe emissions from biomass burning and anthropogenic combustion processes in relation to black carbon (BC) emissions and they estimated (based on observed $\mathrm{Fe} / \mathrm{BC}$ ratios) that $\sim 1.7 \mathrm{Tg}-\mathrm{Fe} \mathrm{yr}^{-1}$ are emitted to the atmosphere via combustion processes. Mahowald et al. (2009) also indicate that humans may significantly impact DFe deposition over oceans by increasing both the acidity of atmospheric aerosol, as well as the DFe emissions from combustion processes. Model projections for the year 2100 suggest that fossil fuel combustion aerosols from shipping could contribute up to $\sim 60 \%$ of DFe deposition to remote oceans (Ito, 2013).

In the present study, the 3-D chemical transport global model TM4-ECPL, that explicitly calculates aqueous-phase chemistry of OXL and the photochemical cycle of the atmospheric $\mathrm{Fe}$ cycle, is used to simulate $\mathrm{Fe}$ deposition over land and oceans, accounting for five Fe-containing dust minerals and for anthropogenic emissions of Fe. Following the scheme of Ito and Xu (2014), dissolution of Fe (Sect. 2) from three pools of minerals (Shi et al., 2012) is considered here to occur by proton-promoted dissolution on three characteristic timescales and by ligand (OXL)-promoted dissolution (as demonstrated by Paris et al., 2011 and parameterized by Johnson and Meskindze, 2013). The calculated
$\mathrm{TFe}$ and DFe global atmospheric budgets and distributions are presented and compared to observations in Sect. 3. The importance of air pollutants for DFe atmospheric concentrations and deposition is investigated in Sect. 4, based on simulations using past and future anthropogenic and biomassburning emissions scenarios. The significant contribution of anthropogenic sources to the dissolution of Fe-containing minerals, their impact on DFe deposition over oceans and the implications of the findings for the biogeochemistry of marine ecosystems are summarized in Sect. 5.

\section{Model description}

The TM4-ECPL global chemistry transport model (Myriokefalitakis et al., 2011; Daskalakis et al., 2015 and references therein) is able to simulate oxidant $\left(\mathrm{O}_{3} / \mathrm{NO}_{x} / \mathrm{HO}_{x} / \mathrm{CH}_{4} / \mathrm{CO}\right)$ chemistry, accounting for non-methane volatile organic compounds (NMVOCs, including isoprene, terpenes and aromatics), as well as all major aerosol components, including secondary aerosols like sulfate $\left(\mathrm{SO}_{4}^{2-}\right)$, nitrate $\left(\mathrm{NO}_{3}^{-}\right)$and ammonium $\left(\mathrm{NH}_{4}^{+}\right)$, using the ISORROPIA II thermodynamic model (Fountoukis and Nenes, 2007) and secondary organic aerosols (SOA) (Tsigaridis and Kanakidou, 2003, 2007). Compared to its parent TM4 model (van Noije et al., 2004), the current version has a comprehensive description of chemistry (Myriokefalitakis et al., 2008) and organic aerosols (Myriokefalitakis et al., 2010). It also accounts for multiphase chemistry in clouds and aerosol water that produces OXL and affects SOA formation (Myriokefalitakis et al., 2011).

For the present study, the TM4-ECPL model is driven by ECMWF (European Center for Medium-Range Weather Forecasts) Interim re-analysis project (ERA-Interim) meteorology (Dee et al., 2011). Advection of the tracers in the model is parameterized using the slopes scheme (Russell and Lerner, 1981 and references therein). Convective transport is parameterized based on Tiedke (1989) and the Olivie et al. (2004) scheme. Vertical diffusion is parameterized as described in Louis (1979). For wet deposition, both largescale and convective precipitation are considered. In-cloud and below-cloud scavenging is parameterized in TM4-ECPL as described in detail by Jeuken et al. (2001). In-cloud scavenging of water-soluble gases is calculated, accounting for the solubility of the gases (effective Henry law coefficients; Tsigaridis et al., 2006; Myriokefalitakis et al., 2011 and references therein). Dry deposition for all fine aerosol components is parameterized similarly to that of nss- $\mathrm{SO}_{4}^{2-}$, which follows Tsigaridis et al. (2006). Gravitational settling (Seinfeld and Pandis, 1998) is applied to all aerosol components and is an important dry deposition process for coarse particles like dust and sea salt. The current model configuration has a horizontal resolution of $3^{\circ}$ in longitude, by $2^{\circ}$ in latitude and 34 hybrid layers in the vertical, from the surface up 
Table 1. Emissions of dust (in $\mathrm{Tg} \mathrm{yr}^{-1}$ ), Fe contained in dust-minerals (illite, kaolinite, smectite, hematite and feldspars; in Tg-Fe yr ${ }^{-1}$ ) and TFe and DFe (in Tg-Fe $\mathrm{yr}^{-1}$ ) used in TM4-ECPL for (a) present (year 2008), (b) past (year 1850) and (c) future (year 2100) simulations.

\begin{tabular}{|c|c|c|c|c|c|}
\hline Species & Year & Biomass burning & Anthropogenic combustion & Ships' oil combustion & Soils \\
\hline Dust & 2008 & & & & 1091 \\
\hline $\mathrm{Fe}$ (illite) & 2008 & & & & 8.473 \\
\hline Fe (kaolinite) & 2008 & & & & 0.871 \\
\hline $\mathrm{Fe}$ (smectite) & 2008 & & & & 17.154 \\
\hline $\mathrm{Fe}$ (hematite*) & 2008 & & & & 5.663 \\
\hline $\mathrm{Fe}$ (feldspars) & 2008 & & & & 2.761 \\
\hline \multirow[t]{3}{*}{$\mathrm{TFe}$} & 1850 & 0.120 & 0.147 & $9.83 \mathrm{E}-05$ & 35.048 \\
\hline & 2008 & 1.200 & 0.768 & 0.015 & \\
\hline & 2100 & 1.456 & 0.158 & 0.002 & \\
\hline \multirow[t]{3}{*}{$\mathrm{DFe}$} & 1850 & 0.013 & 0.011 & 7.99E-05 & 0.125 \\
\hline & 2008 & 0.127 & 0.058 & 0.012 & \\
\hline & 2100 & 0.155 & 0.012 & 0.001 & \\
\hline
\end{tabular}

* Hematite is used here as a surrogate for hematite and goethite.

to $0.1 \mathrm{hPa}$. All simulations have been performed with meteorology of the year 2008 and a model time step of $30 \mathrm{~min}$.

\subsection{Emissions}

TM4-ECPL uses the anthropogenic and biomass-burning emissions (NMVOC, nitrogen oxides $\left(\mathrm{NO}_{x}\right.$ ), $\mathrm{CO}, \mathrm{SO}_{2}$, $\mathrm{NH}_{3}$, particulate organic carbon $(\mathrm{OC})$ and black carbon (BC)) from the ACCMIP database (Lamarque et al., 2013; http://eccad.sedoo.fr/eccad_extract_interface/JSF/ page_meta.jsf). Biogenic emissions (isoprene, terpenes, acetaldehyde, acetone, ethane, ethene, propane, propene, formaldehyde, $\mathrm{CO}$, methyl ethyl ketone, toluene, methanol) come from the MEGAN-MACC biogenic emissions inventory for the year 2008 (Sindelarova et al., 2014). Soil $\mathrm{NO}_{x}$ and oceanic emissions (CO, ethane, ethene, propane, propene) are taken from the POET (Granier et al., 2005) inventory database (http://eccad.sedoo.fr). Oceanic emissions of primary organic aerosol, isoprene, terpenes and sea-salt particles are calculated online, driven by meteorology following Myriokefalitakis et al. (2010). Dust emissions are obtained from the daily AEROCOM inventories (Aerosol Comparison between Observations and Models; Dentener et al., 2006) updated to the year 2008 (E. Vignati, personal communication, 2011). The anthropogenic and biomass-burning emissions (NMVOC, $\mathrm{NO}_{x}, \mathrm{CO}, \mathrm{SO}_{2}, \mathrm{NH}_{3}, \mathrm{OC}$ and $\mathrm{BC}$ ) from the ACCMIP database (Lamarque et al., 2013) for the years: 1850 (hereafter PAST), 2008 (hereafter PRESENT) and for the year 2100 based on the RCP6 emission scenario (hereafter FUTURE), have been used for the different simulations as further explained. A summary of the emissions considered in the model is given in Table S1 in the Supplement.

\subsection{Dust iron-containing mineral emissions}

Various Fe-containing clay minerals (illite, kaolinite and smectite), oxides (hematite and goethite) and feldspars can be found in mineral dust (Nickovic et al., 2013). In the present study, the global soil mineralogy data set developed by Nickovic et al. (2012) at a $30^{\prime \prime}$ resolution $(\sim 1 \mathrm{~km})$ has been initially re-gridded to $1^{\circ} \times 1^{\circ}$ global resolution and applied to the $1^{\circ} \times 1^{\circ}$ daily dust emissions taken into account by TM4-ECPL. The percentage content in Fe of the different Fe-containing minerals of dust that are considered in the model has been taken from Nickovic et al. (2013) (illite 4.8 , kaolinite 0.7 , smectite 16.4 , goethite and hematite 66 and feldspar $2.5 \%$ ). Given this, the annual global mean $\mathrm{Fe}$ content of emitted dust particles in TM4-ECPL is calculated to be $\sim 3.2 \%$. Despite differences in the chemical reactivity and iron content of goethite and hematite (e.g. see http://webmineral.com), these minerals are considered here as one surrogate species, the hematite, used as proxy for $\mathrm{Fe}$ oxides as suggested by Nickovic et al. (2012).

Based on the aforementioned soil mineralogy database ( $F_{\text {MIN_DUST }}$ ), the daily dust emissions (Dustemi) in the model and the Fe content of the minerals $\left(F_{\mathrm{Fe}_{\mathrm{MIN}}}\right)$, TM4-ECPL calculates the $\mathrm{TFe}$ emissions $\left(\mathrm{Fe}_{\mathrm{Emi}}\right)$ from soils as

$F e_{\text {Emi }}=$ Dust $_{\text {Emi }} \times F_{\text {Min_Dust }} \times F_{\mathrm{Fe}_{-} \text {Min }}$.

Thus, the model accounts for the following annual Fe emissions from soils: $\sim 8.473$ from illite, $\sim 0.871$ from kaolinite, $\sim 17.154$ from smectite, $\sim 5.663$ from hematite and goethite and $\sim 2.761 \mathrm{Tg}-\mathrm{Fe} \mathrm{yr}^{-1}$ from feldspars (Table 1 ), total $\sim 35.048 \mathrm{Tg}^{-F e ~} \mathrm{yr}^{-1}$. The DFe emissions in the form of impurities in soils are prescribed in the initial dust sources as $4.3 \%$ on kaolinite and $3 \%$ on feldspars, as suggested by Ito and $\mathrm{Xu}$ (2014) and account for $\sim 0.125 \mathrm{Tg}-\mathrm{Fe}_{\mathrm{yr}}{ }^{-1}$. A summary of dust and $\mathrm{Fe}$-containing mineral emissions used in the TM4-ECPL model is provided in Table 1. The annual mean 
spatial distributions of dust (Fig. S1a in Supplement) and emissions of Fe contained in different minerals (Fig. S1b-f) as calculated by the model are also shown in the supplement.

\subsection{Anthropogenic and biomass-burning iron emissions}

TFe emissions from combustion sources have been estimated at 1.07 from biomass burning, 0.66 from coal combustion (Luo et al., 2008) and $\sim 0.016 \mathrm{Tg}-\mathrm{Fe}_{\mathrm{yr}}{ }^{-1}$ from shipping (Ito et al., 2013), all for the year 2001. For this work, global and monthly mean scaling factors of TFe emissions to those of $\mathrm{BC}(\mathrm{Fe} / \mathrm{BC})$ for each of the above mentioned emission sectors have been derived based on emission estimates provided by Luo et al. (2008) and the BC sources from the ACCMIP database for the year 2001. Furthermore, to calculate the DFe in primary emissions (both in fine and coarse particles), the DFe emission estimates by Ito (2013) of 0.127 from biomass burning, 0.055 from coal combustion and $0.013 \mathrm{Tg}$-Fe $\mathrm{yr}^{-1}$ from shipping, have been used together with the TFe emissions mentioned above for the year 2001 (Luo et al., 2008) to derive mean solubility for each of these three emission categories. These are $\sim 12$ for biomass-burning Fe sources, $\sim 8$ for coal combustion and $\sim 81 \%$ for shipping. The derived $\mathrm{Fe} / \mathrm{BC}$ emission ratios and the mean Fe solubility per source category are then applied to the $\mathrm{BC}$ emissions from the ACCMIP database for the respective year, to compute the past, present and future emissions of TFe and DFe. The computed annual mean surface distributions of the TFe emitted by anthropogenic emissions (including shipping), and biomass burning used in the model $\left(\sim 1.983 \mathrm{Tg}-\mathrm{Fe} \mathrm{yr}^{-1}\right.$ for the year 2008) are depicted in Fig. S1g and h, respectively.

\subsection{Mineral dissolution scheme}

The model calculates the dissolution of Fe-containing minerals in the aerosol water and in the cloud droplets. TM4-ECPL treats the $\mathrm{Fe}$ dissolution as a kinetic process that depends on the concentrations of (i) $\mathrm{H}^{+}$(proton-promoted Fe dissolution) and (ii) OXL (organic ligand-promoted Fe dissolution) in the solution (Fig. 1).

\subsubsection{Proton-promoted iron dissolution}

The proton-promoted dissolution rate of minerals in aerosol and cloud water is calculated by applying the empirical parameterization developed by Lasaga et al. (1994), taking the saturation degree of the solution, the type of each mineral (MIN) as well as the reactivity of Fe species and the ambient temperature into account.

$R_{\mathrm{Fe}}=\mathrm{NFe}_{\mathrm{MIN}} \times K_{\mathrm{MIN}}(T) \times a\left(\mathrm{H}^{+}\right)^{m} \times f_{\mathrm{MIN}} \times A_{\mathrm{MIN}}$,

where $R_{\mathrm{Fe}}$ is the Fe-containing mineral dissolution rate (moles of Fe per gram of MIN pers), $\mathrm{NFe}_{\mathrm{MIN}}$ is the number of moles of Fe per mole of mineral, $K_{\mathrm{MIN}}$ is the temperature $(T)$-dependent dissolution reaction coefficient of the mineral

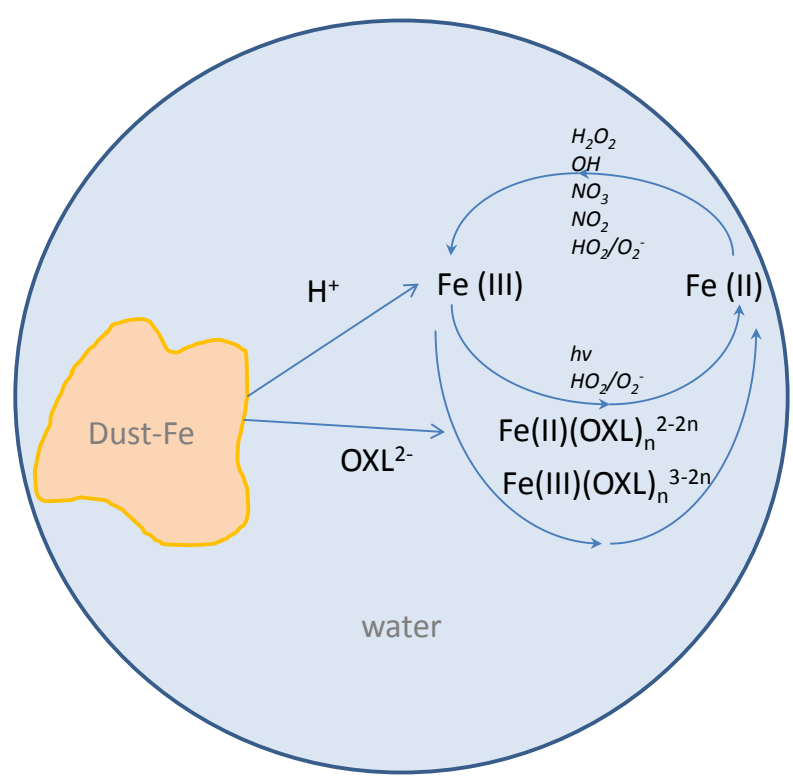

Figure 1. Atmospheric processing of dust-Fe taken into account in the model. Details on the chemical reactions are given in Table S2.

( $\left.m o l \mathrm{~m}^{-2} \mathrm{~s}^{-1}\right), \alpha\left(\mathrm{H}^{+}\right)$is the $\mathrm{H}^{+}$activity in the solution, $m$ is the reaction order with respect to aqueous-phase protons, $A_{\mathrm{MIN}}$ is the specific surface area of the mineral $\left(\mathrm{m}^{2} \mathrm{~g}^{-1}\right)$ and $f_{\text {MIN }}$ accounts for the variation of the rate when deviating from equilibrium. For the present study, the above formulation is applied to each mineral concentration [MIN] (and not to the bulk mass of dust aerosol), since the model describes each mineral with a different tracer in the chemical scheme. For the calculation of the deviation from equilibrium $f_{\mathrm{MIN}}$, the Eq. (3) given by Ito and Xu (2014) is used:

$f_{\mathrm{MIN}}=1-\left(a_{\mathrm{Fe}^{3+}} \times a_{\mathrm{H}^{+}}^{-n_{\mathrm{MIN}}}\right) / \mathrm{Keq}_{\mathrm{MIN}}$,

where $a_{\mathrm{Fe}^{3+}}$ is the concentration of $\mathrm{Fe}$ (III) in the aqueous solution $\left(\mathrm{mol} \mathrm{L}^{-1}\right), n_{\mathrm{MIN}}$ is the stoichiometric ratio (number of moles mobilized per mole of mineral) and $\mathrm{Keq}_{\mathrm{MIN}}$ is the equilibrium constant for iron oxides formation $\left(\mathrm{Fe}(\mathrm{OH})_{3}\right)$. Mineral dissolution rates and the related factors used in this study are listed in Table 2, separating between the DFe (attributed to the emissions), fast-released iron $\left(\mathrm{Fe}_{\mathrm{f}}\right)$, intermediate-released iron $\left(\mathrm{Fe}_{\mathrm{I}}\right)$ and refractory iron $\left(\mathrm{Fe}_{\mathrm{R}}\right)$ (Shi et al., 2011b, 2012), as explicitly parameterized by Ito and $\mathrm{Xu}$ (2014). Aerosol water $\mathrm{pH}$ is calculated by the ISORROPIA II thermodynamic model which solves the $\mathrm{K}^{+}-\mathrm{Ca}^{2+}-\mathrm{Mg}^{2+}-\mathrm{NH}_{4}^{+}-\mathrm{Na}^{+}-\mathrm{SO}_{4}^{2-}-\mathrm{NO}_{3}^{-}-\mathrm{Cl}^{-}-$ $\mathrm{H}_{2} \mathrm{O}$ aerosol system. Based on the composition of mineral dust and sea-salt elements, ISORROPIA II in TM4-ECPL takes the following mean percent mass content of particles into account: $\mathrm{Na}^{+}, 30.6 \%$ on sea salt and $1.7 \%$ on dust; $\mathrm{Ca}^{2+}, 1.2 \%$ on sea salt; $\mathrm{K}^{+}, 2.4 \%$ on dust and $1.1 \%$ on sea salt and $\mathrm{Mg}^{2+}, 1.5 \%$ on dust (as magnesite; Ito and Feng, 2010 - consistent with the observations of Formenti 
Table 2. Constants used for proton-promoted iron dissolution rates and emissions calculations for different types of iron-containing minerals: water-soluble/dissolved iron $(\mathrm{DFe})$; fast-released iron $\left(\mathrm{Fe}_{\mathrm{F}}\right)$; intermediate-released iron $\left(\mathrm{Fe}_{\mathrm{I}}\right)$; slowly released iron $\left(\mathrm{Fe}_{\mathrm{S}}\right)$; refractory iron $\left(\mathrm{Fe}_{\mathrm{R}}\right)$. The parentheses contain the percentage content of Fe type in each mineral.

\begin{tabular}{|c|c|c|c|c|c|c|}
\hline Mineral & Fe type & $K_{\mathrm{MIN}}\left(\mathrm{mol} \mathrm{m}^{-2} \mathrm{~s}^{-1}\right)$ & $\mathrm{m}$ & $A_{\mathrm{MIN}}\left(\mathrm{m}^{2} \mathrm{~g}^{-1}\right)$ & $K_{\text {eq }}$ & $n$ \\
\hline \multirow[t]{2}{*}{ Illite } & $\mathrm{Fe}_{\mathrm{F}}(2.7 \%)^{\mathrm{a}}$ & $1.17 \times 10^{-09} \exp \left[9.2 \times 10^{3}(1 / 298-1 / \mathrm{T})\right]^{\mathrm{b}}$ & $1^{\mathrm{b}, \mathrm{c}}$ & $205^{\mathrm{b}, \mathrm{e}}$ & 41.7 & 2.75 \\
\hline & $\mathrm{Fe}_{\mathrm{S}}(97.3 \%)$ & $1.30 \times 10^{-11} \exp \left[6.7 \times 10^{3}(1 / 298-1 / \mathrm{T})\right]^{\mathrm{d}}$ & $0.39^{\mathrm{d}}$ & $90^{\mathrm{d}}$ & & \\
\hline \multirow[t]{2}{*}{ Smectite } & $\mathrm{Fe}_{\mathrm{I}}(5 \%)^{\mathrm{a}}$ & $8.78 \times 10^{-10} \exp \left[9.2 \times 10^{3}(1 / 298-1 / \mathrm{T})\right]^{\mathrm{b}}$ & $1^{b, c}$ & $125^{\mathrm{b}, \mathrm{e}}$ & 3.31 & 2.85 \\
\hline & $\mathrm{Fe}_{\mathrm{S}}(95 \%)$ & $8.10 \times 10^{-12} \exp \left[6.7 \times 10^{3}(1 / 298-1 / T)\right]^{d}$ & $0.3^{\mathrm{d}}$ & $300^{d}$ & & \\
\hline Hematite* & $\mathrm{Fe}_{\mathrm{R}}(100 \%)^{\mathrm{b}}$ & $1.80 \times 10^{-11} \exp \left[9.2 \times 10^{3}(1 / 298-1 / \mathrm{T})\right]^{\mathrm{b}}$ & $0.5^{\mathrm{e}}$ & $9^{b, a}$ & 0.44 & 2.85 \\
\hline \multirow[t]{2}{*}{ Kaolinite } & $\operatorname{DFe}(4.3 \%)^{\mathrm{b}}$ & & & & & \\
\hline & $\mathrm{Fe}_{\mathrm{R}}(95.7 \%)$ & $4.00 \times 10^{-11} \exp \left[6.7 \times 10^{3}(1 / 298-1 / T)\right]^{\mathrm{f}}$ & $0.1^{f}$ & $20^{\mathrm{f}}$ & $0.44^{\mathrm{b}}$ & $2.85^{\mathrm{b}}$ \\
\hline \multirow[t]{2}{*}{ Feldspars } & $\operatorname{DFe}(3 \%)^{\mathrm{b}}$ & & & & & \\
\hline & $\mathrm{Fe}_{\mathrm{R}}(97 \%)$ & $2.4 \times 10^{-10} \exp \left[7.7 \times 10^{3}(1 / 298-1 / \mathrm{T})\right]^{\mathrm{f}}$ & $0.5^{\mathrm{f}}$ & $1^{\mathrm{f}}$ & $0.44^{\mathrm{b}}$ & $2.85^{\mathrm{b}}$ \\
\hline
\end{tabular}

${ }^{\mathrm{a}}$ Shi et al, 2011b; ${ }^{\mathrm{b}}$ Ito and Xu, 2014; ${ }^{\mathrm{c}}$ Lanzl et al., 2012; ${ }^{\mathrm{d}}$ Ito, 2012; ${ }^{\mathrm{e}}$ Bonneville et al., 2004; ${ }^{\mathrm{f}}$ Meskhidze et al., 2005 and references therein. ${ }^{*}$ Hematite is used here as a surrogate for hematite and goethite.

et al., 2008) and $3.7 \%$ on sea salt (http://geology.utah.gov/ online_html/pi/pi-39/pi39pg9.htm); $\mathrm{Cl}^{-}, 55 \%$ on sea salt; and $\mathrm{SO}_{4}^{2-}, 7.7 \%$ on sea salt. The global soil mineralogy data set (Nickovic et al., 2012) has been applied on dust emissions to calculate the concentrations of $\mathrm{Ca}^{2+}$ on dust particles (i.e. calcite $\left(\mathrm{CaCO}_{3}\right)$ and gypsum $\left.\left(\mathrm{CaSO}_{4}\right)\right)$.

Aerosol $\mathrm{pH}$ and water are calculated here for each aerosol mode (Fig. S2a for the fine mode and Fig. S2b for the coarse mode). The $\mathrm{pH}$ values for each aerosol mode are calculated by the thermodynamic equilibrium model ISORROPIA II assuming internal mixing of the aerosols (Fountoukis and Nenes, 2007). Briefly, for each mode (fine and coarse) sulfate, nitrate, ammonium and sea-salt (i.e. $\mathrm{K}^{+}$; $\left.\mathrm{Ca}^{2+} ; \mathrm{Mg}^{2+} ; \mathrm{Na}^{+} ; \mathrm{SO}_{4}^{2-} ; \mathrm{Cl}^{-}\right)$aerosols are assumed to be internally mixed. Carbonates $\left(\mathrm{CaCO}_{3}, \mathrm{MgCO}_{3}\right)$ and gypsum $\left(\mathrm{CaSO}_{4}\right)$ are considered to be present in the silt soil particles (Meskhidze et al., 2005), with their impact on the coarse particulate $\mathrm{H}^{+}$and $\mathrm{H}_{2} \mathrm{O}$, to be calculated interactively by the ISORROPIA II. The dissolved $\mathrm{Ca}^{2+}$ and $\mathrm{Mg}^{2+}$ is distributed by the thermodynamic model among all possible solids.

In TM4-ECPL, in-cloud $\mathrm{pH}$ (Fig. S2c at $\sim 850 \mathrm{hPa}$ and Fig. S2d for zonal mean) is controlled by strong acids (sulfates, $\mathrm{SO}_{4}^{2-}$; methanesulfonate, $\mathrm{MS}^{-}$; nitric acid, $\mathrm{HNO}_{3}$; nitrate ion, $\mathrm{NO}_{3}^{-}$), bases (ammonium ion, $\mathrm{NH}_{4}^{+}$), as well as by the dissociations of hydrated $\mathrm{CO}_{2}, \mathrm{SO}_{2}, \mathrm{NH}_{3}$ and of oxalic acid (Myriokefalitakis et al., 2011). Crustal and sea-salt elements are not considered for $\mathrm{pH}$ calculations in the cloud chemical scheme.

\subsubsection{Organic ligand-promoted iron dissolution}

Recent laboratory studies show a positive linear correlation between iron solubility and organic ligands concentrations (e.g. Paris and Desboeufs, 2011 and references therein). Two mechanisms have been proposed concerning the mineral dissolution in the presence of organic ligands: (i) the non- reductive (Stumm and Morgan, 1996) and (ii) the reductive (Stumm and Sulzberger, 1992) ligand-promoted dissolution. Experimental studies by Paris and Desboeufs (2013) indicate that certain organic ligands (including OXL) enhance Fe dissolution from mineral dust. This ligand-promoted dissolution was accompanied by increased concentrations of dissolved $\mathrm{Fe}(\mathrm{II})$ and was probably related to the ability of organic ligands to act as electron donors.

In the present study, we follow the recommendations of Johnson and Meskhidze (2013) based on the experiments by Paris et al. (2011) for OXL-promoted Fe dissolution of hematite, goethite and illite in cloud droplets and rainwater. Because the mineral database used for this study considers the average iron oxides (the goethite and hematite content) as a single iron oxide species (hematite), we take the fractional OXL-promoted $\mathrm{Fe}$ dissolution rates for hematite $\left(\alpha-\mathrm{Fe}_{2} \mathrm{O}_{3}\right)$ and goethite $(\alpha-\mathrm{FeO}(\mathrm{OH}))$ into account proposed by Johnson and Meskhidze (2013), as presented in Table 3. The average values of relative proportions of $\mathrm{Fe}$ in the form of hematite and goethite to total iron oxide are based on experimental data for dust sources, compiled by Formenti et al. (2014), with their abundance in total iron oxide at $\sim 36$ and $\sim 64 \%$, respectively.

$\mathrm{DFe}$ production during the organic ligand-promoted $\mathrm{Fe}$ dissolution is considered here to be in the form of $\mathrm{Fe}(\mathrm{II})$ -oxalato complexes in the aqueous phase (i.e. in the ferrous oxidation state) and it is only applied to water droplets following the recommendations of the laboratory studies by Paris et al. (2011) and Paris and Desboeufs (2013). The aforementioned experiments have been performed with OXL concentrations found typically in rainwater and cloud droplets $(0-8 \mu \mathrm{M})$, with a $\mathrm{pH}$ of 4.5 and dust concentrations of about $15 \mathrm{mg} \mathrm{L}^{-1}$. Indeed, properties of the aqueous solution of clouds differ significantly to those of aerosols, with higher $\mathrm{pH}$ values (e.g. $>4$ ), lower aqueous-phase dust concentrations $\left(<50 \mathrm{mg} \mathrm{L}^{-1}\right)$ and lower ionic strength (Shi et 
Table 3. Constants used for ligand (oxalate)-promoted iron dissolution from illite and hematite.

\begin{tabular}{|c|c|c|c|}
\hline Mineral & $\begin{array}{l}\text { Dissolution rates } \\
\left(\mathrm{mol} \mathrm{Fe} \mathrm{m} \mathrm{m}^{-2} \mathrm{~s}^{-1}\right)\end{array}$ & $\left.\mathrm{A}_{\min } \mathrm{m}^{2} \mathrm{~g}^{-1}\right)$ & Ref. \\
\hline Illite & $3.00 \times 10^{-10}\left[\mathrm{OXL}^{2-}\right]+6 \times 10^{-11}$ & 205 & $\begin{array}{l}\text { Paris et al. (2011); } \\
\text { Johnson and Meskhidze (2013) }\end{array}$ \\
\hline Hematite* & $\begin{array}{l}0.36 \times\left(3.00 \times 10^{-12}\left[\mathrm{OXL}^{2-}\right]-2 \times 10^{-12}\right) \\
+0.64 \times\left(1.00 \times 10^{-11}\left[\mathrm{OXL}^{2-}\right]+7 \times 10^{-13}\right)\end{array}$ & 9 & $\begin{array}{l}\text { Paris et al. (2011); } \\
\text { Johnson and Meskhidze (2013) }\end{array}$ \\
\hline
\end{tabular}

* Hematite is used here as a surrogate for hematite and goethite.

al., 2012). On the other hand, the liquid aerosol content of typical continental aerosols can vary between $\sim 10^{-12}$ and $10^{-11} \mathrm{~cm}^{3} \mathrm{~cm}^{-3}$ air, depending on the relative humidity, and the aerosol $\mathrm{pH}$ can vary between 1 and 4 (McNeill et al., 2012). Aqueous-phase OXL concentrations are significantly related to the transfer of small gas-phase polar compounds (e.g. glyoxal) to the liquid-phase (Carlton et al., 2007), a process that depends proportionally on the volume of the aqueous medium and on the $\mathrm{pH}$ of the solution. On the other hand, high acidic $\mathrm{pH}$ in the condense phase tends to favour the production of oligomeric structures rather than OXL (e.g. Lim et al., 2010, 2013). Thus, under such conditions of low aqueous-phase OXL concentrations, the ligand-promoted $\mathrm{Fe}$ dissolution may be suppressed significantly.

\subsection{Aqueous-phase chemistry scheme}

The global model simulates aqueous-phase chemistry in aerosol water and cloud droplets as described in Myriokefalitakis et al. (2011). To parameterize the Fe speciation through the photochemical cycling of $\mathrm{Fe}$ (III) / Fe(II), the aqueousphase chemical scheme has been further developed to account for the mineral-Fe dissolution processes and the ferricand ferrous oxalato complexes speciation (Fig. 1), taking recent global modelling studies (Johnson and Meskhidze, 2013; Lin et al., 2014 and references therein) into account. Here, we use both the proton-promoted dissolution scheme as presented by Ito and Xu (2010) together with the ligandpromoted dissolution scheme as experimentally proposed by Paris et al. (2011). In Table S2 the updates in the chemical scheme of TM4-ECPL concerning Fe aqueous-phase chemistry that are adopted for the present study are listed. Fe aqueous-phase chemistry affects OXL net chemical production in two different ways: it reduces OXL by its oxidation to $\mathrm{CO}_{2}$ (Ervens et al., 2003; Lin et al., 2014) during the rapid photolysis of ferrous dioxalato complexes (Table S2), while it increases OXL production due to the enhancement in $\mathrm{OH}$ radical production via the Fenton reaction (Table S2). These also affect modelled OXL concentrations that are reevaluated in the Supplement Fig. S3 by comparison with observations compiled by Myriokefalitakis et al. (2011).

\subsection{Iron dissolution scheme}

Johnson and Mekhidze (2013) concluded that protons effectively promote $\mathrm{Fe}$-containing mineral dissolution at rather acidic $\mathrm{pH}$ values $(\mathrm{pH}<\sim 2$ ), while OXL-promoted dissolution happens at higher $\mathrm{pH}$ values $(\mathrm{pH}>3)$. To investigate the sensitivity of our chemical scheme to $\mathrm{pH}$ and OXL levels, we have performed box-model simulations to compare the iron solubility from our iron dissolution scheme in different acid and oxalate-load cases. The box-model calculations have been performed for dust concentrations $1 \mathrm{mg} \mathrm{L}^{-1}$, $\mathrm{pH}$ values of $1.5,4.5$ and 8.5 and for initial oxalic acid concentrations of $0,4.5$ and $8 \mu \mathrm{M}$. The percentage content of Fe in dust has been taken from Nickovic et al. (2013) as in the global TM4ECPL model. Moreover, to take the Fe speciation due to aqueous-phase photochemical reactions into account, the box model also considers initial concentrations of $\left[\mathrm{H}_{2} \mathrm{O}_{2}\right]=1$, $\left[\mathrm{O}_{3}\right]=10^{-6},[\mathrm{OH}]=10^{-7}$ and $\left[\mathrm{HO}_{2}\right]=10^{-7} \mu \mathrm{M}$. Note that during the simulation, $\mathrm{pH}$ values remain constant, but iron, oxalic acid as well as all other species' concentrations change following the chemical scheme as described in Table S2. In Fig. S4, the $\mathrm{SFe}$ and the corresponding ferrous (SFe(II); $\mathrm{SFe}(\mathrm{II})=100 \times \mathrm{Fe}$ (II) $/ \mathrm{TFe}$ ) and ferric $(\mathrm{SFe}(\mathrm{III}) ; \mathrm{SFe}(\mathrm{III})=100 \times \mathrm{Fe}(\mathrm{III}) / \mathrm{TFe})$ solubility fractions calculated for each simulation are presented.

According to our calculations after 10 days $(240 \mathrm{~h}$ of simulation), in the absence of OXL concentrations but in highly acidic $\mathrm{pH}$ values of 1.5 , the $\mathrm{SFe}$ was calculated to reach $\sim 10 \%$ (Fig. S4a), while at $\mathrm{pH}=4.5$ the SFe reached only $\sim 0.2 \%$ in the form of $\mathrm{Fe}$ (II) (Fig. S4b) but at basic $\mathrm{pH}$ values of 8.5 the $\mathrm{SFe}$ was close to zero (Fig. S4c). In the presence of an initial OXL concentration of $4.5 \mu \mathrm{M}$, the box model calculates no significant change of SFe for highly acidic $\mathrm{pH}$ of 1.5 (Fig. S4d) compared to the absence of OXL (since $\mathrm{pH}$ values remain constant during the simulation), while for $\mathrm{pH}=4.5$ the $\mathrm{SFe}$ reached $\sim 0.05 \%$ in the form of $\mathrm{Fe}$ (II) (Fig. S4e), and for $\mathrm{pH}=8.5$ the $\mathrm{SFe}$ increased up to $\sim 3.5 \%$ (also in the form of $\mathrm{Fe}(\mathrm{II})$ ). This can be explained because at rather basic $\mathrm{pH}$ levels, the mole fraction of oxalic acid $(p \mathrm{Ka} 1=1.27$ and $\mathrm{pKa} 2=4.27$ ) is higher compared to acidic $\mathrm{pH}$ conditions and thus the organic ligand-promoted dissolution tends to be more effective (Johnson and Meskhidze, 2013). In the case of high oxalic acid concentrations of $8 \mu \mathrm{M}$ (Fig. S4g-i), the box 
a)

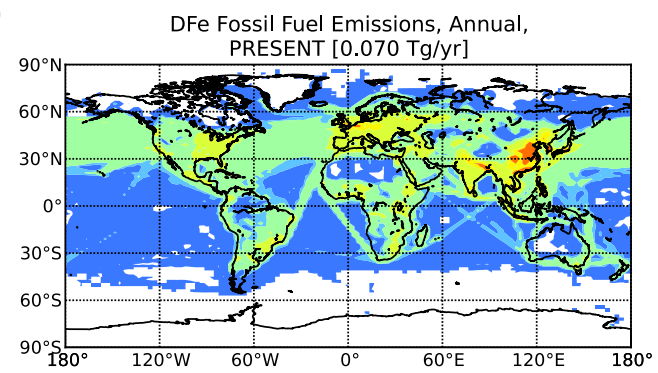

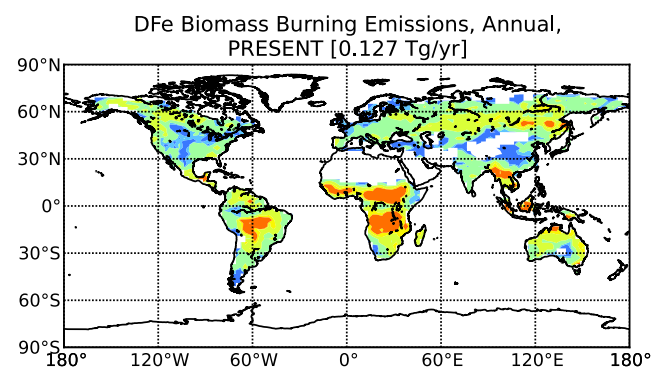

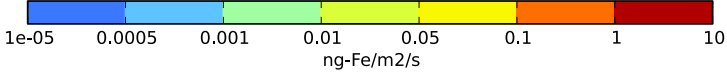

c)

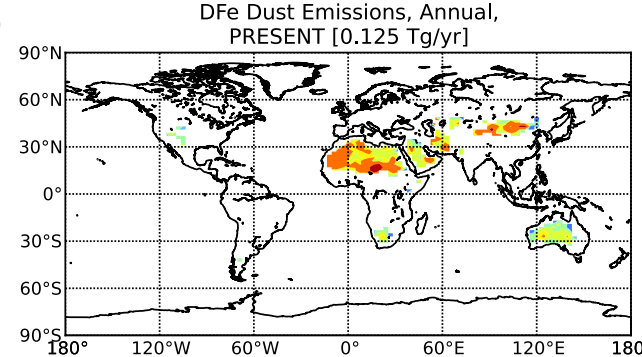

d)
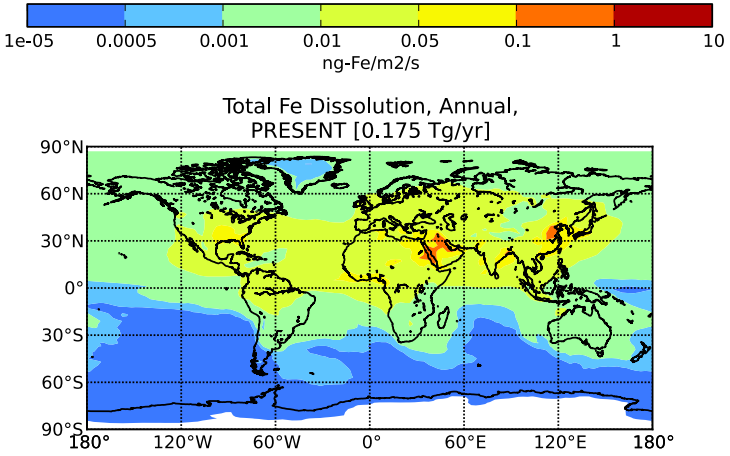
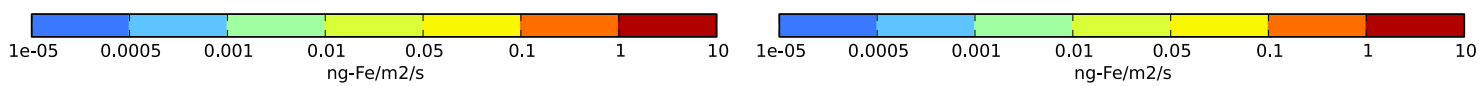

Figure 2. Annual averaged distributions (in ng-Fe $\mathrm{m}^{-2} \mathrm{~s}^{-1}$ ) of (a) total anthropogenic DFe primary emissions, (b) total biomass-burning DFe emissions, (c) total DFe mineral emissions and (d) total mineral-Fe dissolution flux as calculated by TM4-ECPL for the present atmosphere.

model calculates that $\mathrm{Fe}$ dissolution is effectively promoted by ligands. Indeed, for $\mathrm{pH}=8.5$ and initial $[\mathrm{OXL}]=8 \mu \mathrm{M}$ (Fig. S4g), the box model calculates that $\mathrm{SFe}$ reaches $\sim 6 \%$. However, for $\mathrm{pH}=1.5$ and $[\mathrm{OXL}]=8 \mu \mathrm{M}$ the $\mathrm{SFe}$ reaches also high values, although this can mainly be attributed to the proton-promoted dissolution since the mole fraction of oxalate is extremely low at these $\mathrm{pH}$ values. In contrast, for the case of a mid-range $\mathrm{pH}$ value (4.5), $\mathrm{SFe}$ reaches $\sim 6 \%$ as a result of mainly ligand-promoted dissolution (Fig. S4h) and to a lesser extent to the proton-promoted one, consistent with the no-OXL case, as shown in Fig. S4b.

Although the aforementioned sensitivity box-modelling studies show the significance between the proton- and ligandpromoted Fe dissolution depending on the chemical conditions, the proton-promoted dissolution is expected to be more important under atmospheric conditions. While high basic $\mathrm{pH}$ values are associated with dust alkalinity (Ito and Feng, 2010) located close to dust sources, no significant oxalic acid sources, which are controlled mainly from biogenic NMVOC emissions and cloudiness (Myriokefalitakis et al., 2011), are expected to be found near the desert regions (e.g. the Sahara).

\section{Results and discussion}

\subsection{Primary and secondary sources of dissolved iron}

In Fig. 2, the annual mean primary DFe emissions from fossil fuel combustion processes (including oil combustion from ships) (Fig. 2a), biomass burning (Fig. 2b) and from Fe-containing mineral (Fig. 2c) sources are shown together with the annual mean total mineral-Fe dissolution flux (sum of proton- and organic ligand-promoted Fe dissolution fluxes; secondary DFe sources) as calculated by the model (Fig. 2d). The model takes $\sim 0.070 \mathrm{Tg}-\mathrm{Fe} \mathrm{yr}^{-1}$ of DFe anthropogenic emissions into account, with most of them occurring over densely populated regions of the globe (the midlatitudes of the Northern Hemisphere, e.g. China, Europe and the US; $\sim 0.1-1 \mathrm{ng}-\mathrm{Fe} \mathrm{m}^{-2} \mathrm{~s}^{-1}$ ), but also in the remote oceans (e.g. North Atlantic Ocean, North Pacific Ocean), due to oil-combustion processes downwind of shipping lanes (up to $0.05 \mathrm{ng}-\mathrm{Fe} \mathrm{m}^{-2} \mathrm{~s}^{-1}$ ). Primary emissions of DFe from biomass burning (Fig. 2b) peak over tropical forested areas $\left(\sim 1 \mathrm{ng}-\mathrm{Fe} \mathrm{m}^{-2} \mathrm{~s}^{-1}\right)$ and according to model calculations, biomass burning contributes about $\sim 0.127 \mathrm{Tg}-$ $\mathrm{Fe} \mathrm{yr}^{-1}$, showing maxima over central Africa and Amazonia during the dry season. DFe emissions associated with mineral dust (Fig. 2c) of $\sim 0.125 \mathrm{Tg}$-Fe yr ${ }^{-1}$, are emitted mainly over the Saharan desert region; however, important emissions 
a)

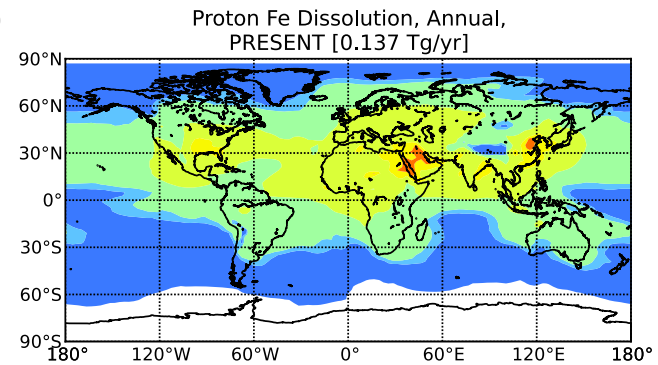

b)

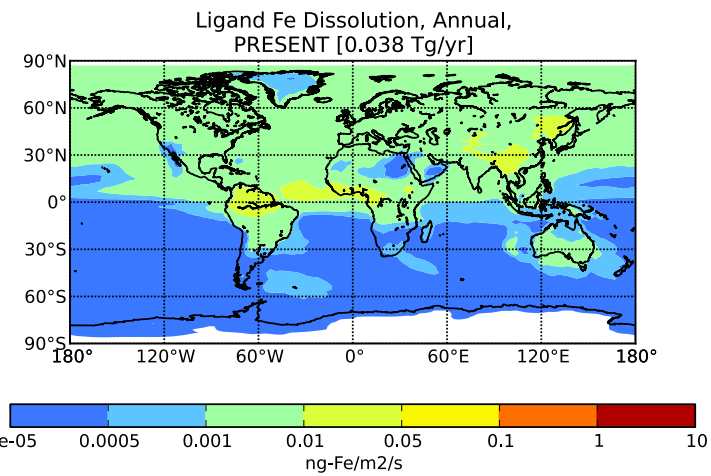

Figure 3. Annual averaged (a) proton-promoted and (b) ligand-promoted mineral-Fe dissolution flux (in ng-Fe $\mathrm{m}^{-2} \mathrm{~s}^{-1}$ ) as calculated by TM4-ECPL for the present atmosphere.

are also found over other desert areas of the globe (e.g. the Gobi desert, in the Middle East and Australia).

The secondary sources of DFe in the atmosphere result from both the proton- and ligand-promoted dissolution processes of Fe-containing minerals in the model (Fig. 2d). The total annual mineral-Fe dissolution flux is calculated to be $\sim 0.175 \mathrm{Tg}-\mathrm{Fe} \mathrm{yr}^{-1}$ of DFe by TM4-ECPL. As shown in Fig. 2d, most of the dissolution occurs downwind of the dust source region, where long- and regional-range transport of natural and anthropogenic pollution sources enhance the release of DFe from the minerals. Thus, the model calculates maximum dissolution fluxes over the Persian Gulf, downwind of the Sahara and Beijing, downwind of the Gobi desert $\left(\sim 1 \mathrm{ng}-\mathrm{Fe} \mathrm{m}^{-2} \mathrm{~s}^{-1}\right)$. However, enhanced mineral-Fe dissolution fluxes $\left(\sim 0.1 \mathrm{ng}-\mathrm{Fe} \mathrm{m}^{-2} \mathrm{~s}^{-1}\right)$ are calculated over the whole area of the Middle East, the eastern Mediterranean basin, as well as over the remote oceans like the tropical Atlantic Ocean, and India and the outflow of Asia to the Pacific Ocean.

\subsection{Proton- versus organic ligand-promoted mineral iron mobilization}

The proton- and the organic ligand-promoted dissolution of Fe-containing minerals are compared in Fig. 3a and b, respectively. According to TM4-ECPL calculations on a global scale, almost $80 \%$ of dust-Fe dissolution occurs through proton-promoted dissolution (Fig. 3a; $\sim 0.137 \mathrm{Tg}^{-F e} \mathrm{yr}^{-1}$ ), where high proton concentrations destabilize $\mathrm{Fe}$-oxygen ( $\mathrm{Fe}-\mathrm{O})$ bonds in the crystal lattice of the Fe-containing minerals. Proton-promoted Fe dissolution dominates downwind of dust source areas and heavy population regions (e.g. Beijing; $\sim 1.00 \mathrm{ng}-\mathrm{Fe} \mathrm{m}^{-2} \mathrm{~s}^{-1}$ ) where atmospheric acidity is high due to $\mathrm{SO}_{x}$ and $\mathrm{NO}_{x}$ anthropogenic emissions. On the other hand, because of long-range transport, relatively high rates of organic ligand-promoted dissolution $(\sim 0.1 \mathrm{ng}$ $\mathrm{Fe} \mathrm{m}^{-2} \mathrm{~s}^{-1}$ ) are calculated over central Africa, Amazonia and the equatorial Atlantic Ocean (Fig. 3b), where biogenic
NMVOC oxidation and cloudiness lead to enhanced OXL aqueous-phase formation (Myriokefalitakis et al., 2011).

\subsection{Iron concentrations}

The calculated global annual mean TFe and DFe atmospheric surface distributions are shown in Fig. 4a and b (note differences in scales), respectively (the dissolved $\mathrm{Fe}$ (III) and $\mathrm{Fe}$ (II) in Fig. S5a-b and c-d in the Supplement, respectively), and the fractions of $\mathrm{Fe}$ (II) to DFe are presented in Fig. 4c. Maxima annual mean concentrations of more than $100 \mu \mathrm{g}-\mathrm{Fe} \mathrm{m}^{-3}$ are calculated to occur over the Sahara and Gobi deserts near the surface (Fig. 4a). However, the outflow from these source regions transports TFe over the global ocean, with the highest impact to be calculated for the Northern Hemisphere (Fig. 4a). The DFe concentrations (sum of $\mathrm{Fe}(\mathrm{III})$ and $\mathrm{Fe}$ (II)) are calculated to be about 3 orders of magnitude lower than the TFe (Fig. 4b). As for TFe, the outflow from the continental source regions is clearly seen in the calculated DFe distributions. The enhanced concentrations of Fe (III) over polluted regions, determine the importance of atmospheric acidity and anthropogenic DFe emissions (Fig. S5a). Over central South America, Asia and Indonesia, high concentrations of DFe $\left(\sim 50-100 \mathrm{ng}-\mathrm{Fe} \mathrm{m}^{-3}\right)$ are calculated both due to biomass-burning DFe emissions but also due to organic ligand-promoted dissolution, which is enhanced in these areas by the OXL produced from oxidation of emitted biogenic NMVOCs via clouds.

African $\mathrm{Fe}$ sources also affect the middle tropospheric DFe concentrations through atmospheric transport along the tropical Hadley cell. Model calculations show that Fe(III) (Fig. S5b) and Fe(II) (Fig. S5d) have significant concentrations in the middle troposphere owing to transport from the source regions. Note, however, that in-cloud and in-aerosol water aqueous-phase chemical processing also transforms a significant part of TFe to DFe in the upper troposphere.

Model calculations also demonstrate the importance of photochemical redox cycling of $\mathrm{Fe}$ (III) $/ \mathrm{Fe}$ (II) in the aqueous-phase (aerosols and clouds) of the atmosphere. Fig- 
a)



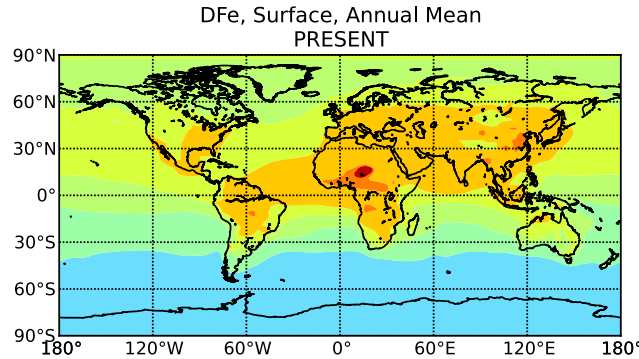
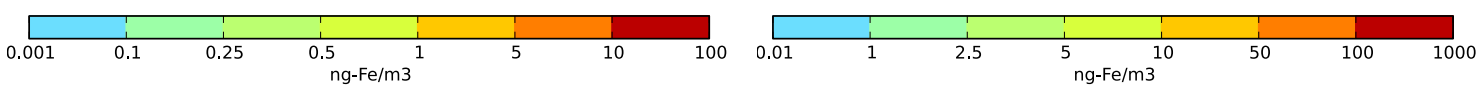

c) $\mathrm{Fe}(\mathrm{II}) / \mathrm{DFe}$, Surface, Annual Mean

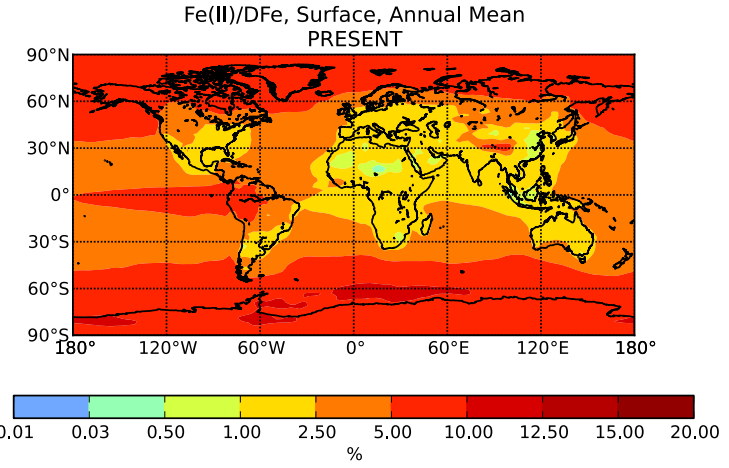

Figure 4. Annual averaged (a) proton-promoted and (b) ligand-promoted mineral-Fe dissolution flux (in $n g-F e m^{-2} s^{-1}$ ) as calculated by TM4-ECPL for the present atmosphere.

ure $4 \mathrm{c}$ shows the percentage contribution of $\mathrm{Fe}(\mathrm{II})$ to $\mathrm{DFe}$ as computed by the model, denoting that the calculated Fe(II) concentrations are an important part of DFe atmospheric burden; regionally reaching up to $20 \%$ of the total dissolved mass far from the dust source areas e.g. the remote ocean. This ratio also exceeds $10 \%$ at several other locations around the globe, in particular over the tropical Pacific and the Southern Ocean; implying that chemical aging of dust due to atmospheric processing and long-range transport enhances the production of $\mathrm{Fe}(\mathrm{II})$ significantly. As also discussed in Sect. 2.6, in relatively basic $\mathrm{pH}$ environments (e.g. the Southern Ocean due to the buffering capacity of sea-salt particles; see Fig. S2a, b) and due to high OXL concentrations (e.g. tropical Pacific ocean) the production of $\mathrm{Fe}$ (II) is favoured (Fig. S4e and h, respectively). Thus, our model calculations indicate that the enhanced fraction of $\mathrm{Fe}(\mathrm{II})$ over the remote oceans (Fig. 4c), characterized by low concentrations of dust and non-negligible OXL concentrations (see Fig. S3) due to the aqueous-phase oxidation of organic compounds of marine origin NMVOCs (e.g. isoprene) could be attributed to the production of ferrous oxalato complexes.

TM4-ECPL calculates a global TFe atmospheric burden of $\sim 0.857 \mathrm{Tg}-\mathrm{Fe}$ and almost 35 times lower atmospheric burden of the $\mathrm{DFe} \sim 0.024 \mathrm{Tg}-\mathrm{Fe}(\sim 0.023 \mathrm{Tg}-\mathrm{Fe}$ as $\mathrm{Fe}$ (III) and $\sim 0.001 \mathrm{Tg}-\mathrm{Fe}$ as $\mathrm{Fe}(\mathrm{II})$ ). This also indicates the existence of a large TFe reservoir that can be mobilized under favourable conditions. The total SFe (Fig. S6a) is calculated to vary spa- tially with minima over the dust sources $(\sim 1 \%)$ and maxima over the south equatorial regions $(\sim 5 \%)$. SFe due to dust aerosols is attributed primarily to the atmospheric processing and to the (low) initial dust solubility. These low SFe values over dust source regions can be also explained by the suppressed mineral-Fe dissolution because of the enhanced buffering capacity (as well as the low water associated with dust aerosols near their sources), the low acidity because of the low amounts of acidic inorganic compounds from anthropogenic pollution and the lack of organic ligands (e.g. OXL) over large dust outbreaks (e.g. the Sahara) (Fig. S6b). On the other hand, the model calculates higher SFe values $(\sim 2.5$ $5 \%$ ) of dust aerosols over regions characterized by low dust concentrations but high amounts of anthropogenic pollution (e.g. over the Indian Ocean). However, the co-existence of relatively high dust concentrations and high amounts of anthropogenic pollutants tend to enhance mineral-Fe atmospheric processing significantly and thus $\mathrm{SFe}(\sim 5 \%)$, as in the case of the Persian Gulf and eastern Mediterranean (Fig. S6b). Fe-containing combustion aerosols of anthropogenic origin (Fig. S6c) are also calculated to contribute significantly to $\mathrm{SFe}(\sim 2.5 \%)$ over high population regions (e.g. the US, central Europe and China). Due to the longrange transport in the Northern Hemisphere, enhanced $\mathrm{SFe}$ is simulated also over the North Atlantic and Pacific oceans $(\sim 1.5 \%)$. Additionally, biomass-burning processes are calculated to increase $\mathrm{SFe}$, especially over the Southern Hemi- 

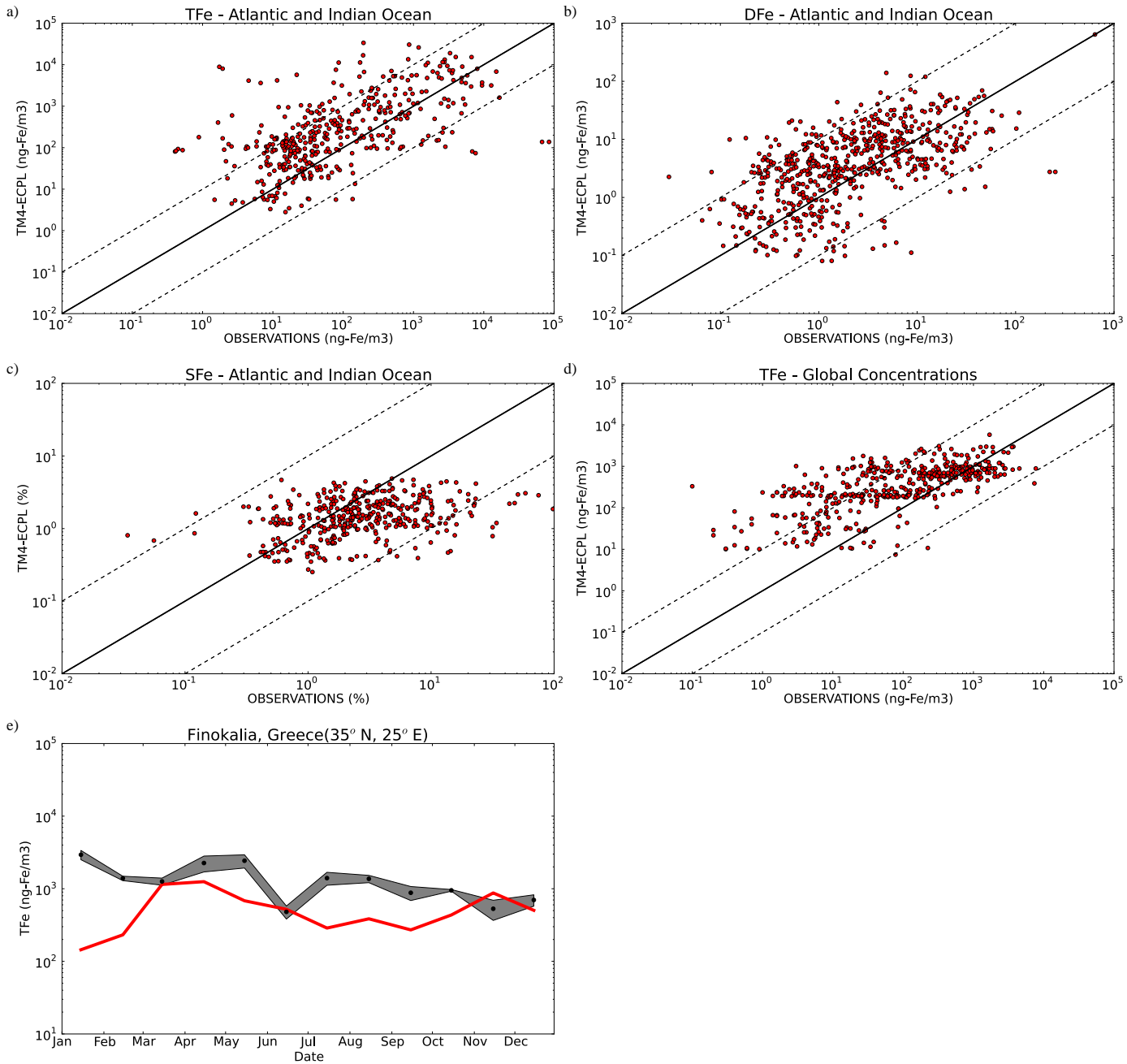

Figure 5. Log-scatter plot of model (y-axis) comparison with cruise observations over the Atlantic Ocean (Baker et al., 2013) and Indian Ocean (Witt et al., 2006) ( $x$ axis) for (a) TFe, (b) the DFe and (c) the SFe fractions in ambient aerosols, (d) TFe comparison with global observations from Mahowland et al. (2005) and (e) time series of monthly variation of TFe in ambient aerosols at Finokalia station (Koulouri et al., 2008); monthly mean observations are marked with dots, their variability is shown with the dashed area, model results are plotted by the black continuous line. In the scatter plots, the continuous black line shows the $1: 1$ correlation, while the dashed lines show the $10: 1$ and $1: 10$ relationships.

sphere. The atmospheric transport of dissolved Fe-containing combustion aerosols from central Africa, Amazonia and Indonesia over the Southern Pacific, Atlantic and Indian oceans (from the equator to $\sim 50^{\circ} \mathrm{S}$ ) is found to increase the $\mathrm{SFe}$ $(\sim 5 \%)$ significantly. Overall, model calculations denote that from the computed global average $\mathrm{SFe}$ of about $2.8 \%, 1.3$ comes from dust, 1.2 from biomass-burning aerosols and $0.3 \%$ from fossil fuel combustion processes. The average lifetime of TFe is calculated to be about 5 days while that of $\mathrm{DFe}$ is found to be longer ( $\sim 6$ days on average) due to DFe association with atmospheric aerosol that has been transported and processed in the atmosphere and thus resides overall in smaller-size aerosols than TFe. In our model, DFe resides mostly in small particles $(\sim 60 \%)$ and thus is more effectively transported in the atmosphere, reaching the global ocean, compared to the bulk TFe mass that is carried mainly by coarse aerosols $(\sim 80 \%)$.

\subsection{Model iron concentration evaluation}

Observations of total and dissolved-Fe concentrations in ambient aerosols near the surface are valuable to evaluate our understanding of the $\mathrm{Fe}$ cycle as parameterized in the models. TM4-ECPL daily mean results are validated here against daily observations of total (Fig. 5a) and dissolved $\mathrm{Fe}$ (Fig. 5b) associated with atmospheric aerosols over the Atlantic Ocean (Baker et al., 2013) and the Indian Ocean (Witt et al., 2006) as compiled by Sholkovitz et al. (2013). Figure $5 \mathrm{c}$ also presents the comparison of daily solubility fractions of the above observations versus the respective calculated 
a)

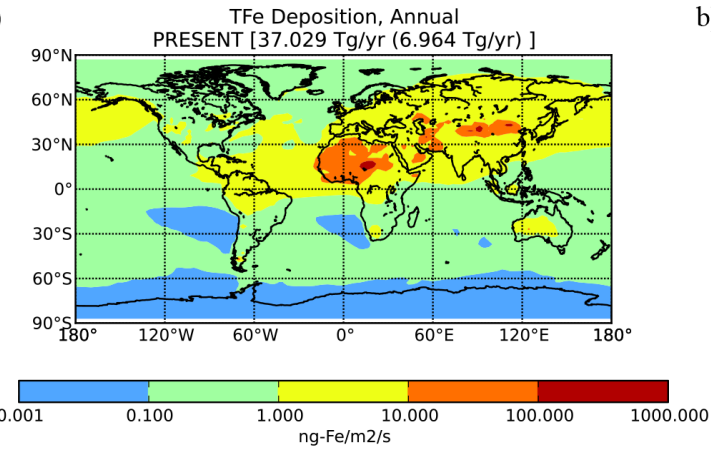

c)

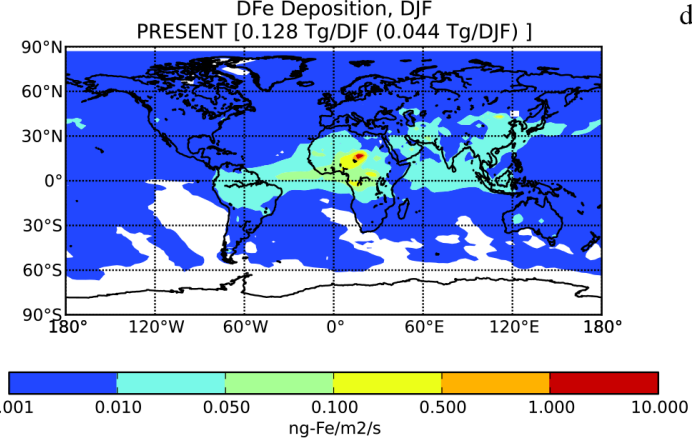

e)

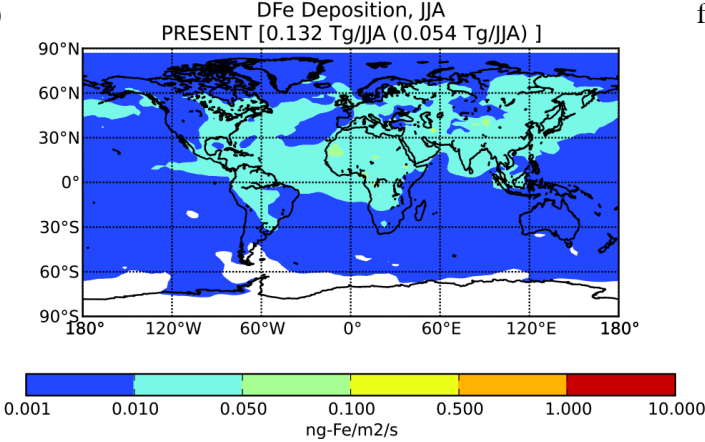

b)

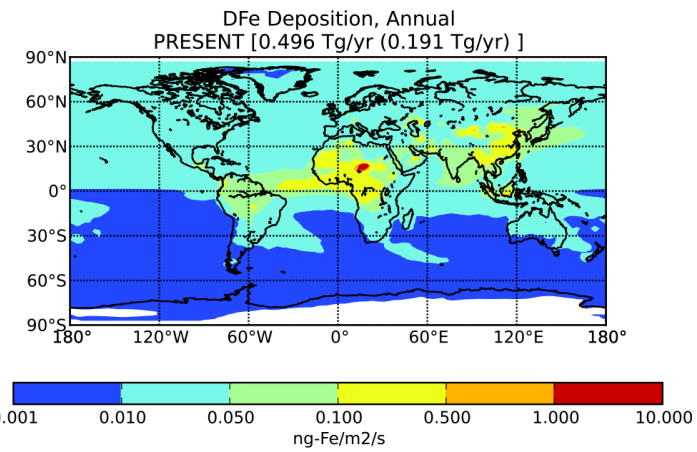

d)

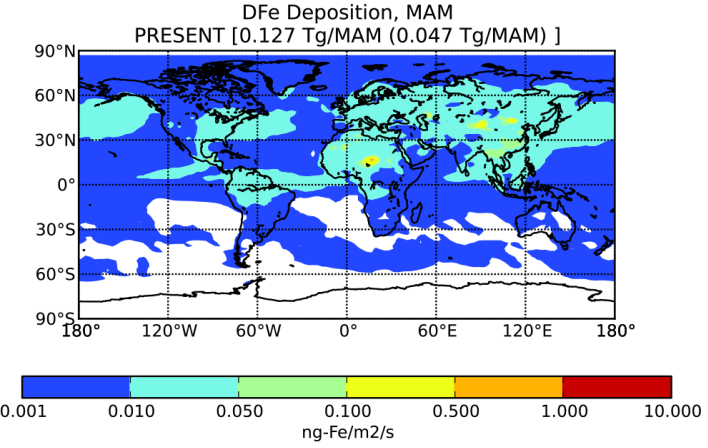

f)

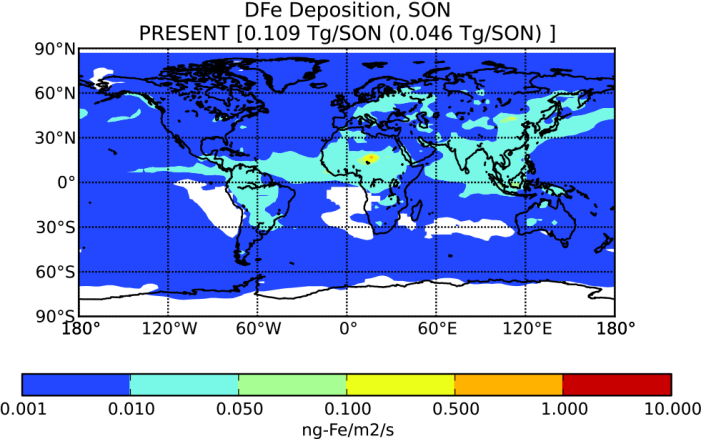

Figure 6. Calculated present annual deposition (in $n g-F e \mathrm{~m}^{-2} \mathrm{~s}^{-1}$ ) for (a) TFe, (b) DFe, and the seasonal DFe deposition fluxes for (c) December, January and February (DJF), (d) March, April and May (MAM), (e) June, July and August (JJA) and (f) September, October and November (SON). In brackets (parentheses) the amounts of Fe deposition over the globe (only over oceans) are provided.

fractions by the model. In addition, Fe aerosol data compiled by Mahowald et al. (2005) are compared with model results in Fig. 5d. The seasonality of TFe in the eastern Mediterranean as measured and compiled by Koulouri et al. (2008) at Finokalia station (http://finokalia.chemistry.uoc.gr/) is also compared to monthly model results (Fig. 5e).

The comparisons presented in Fig. 5 show that the model reasonably simulates the observed concentration of total and dissolved $\mathrm{Fe}$ in the ambient aerosols over oceans (scatter plots in Fig. 5a, b and c). In the eastern Mediterranean, when comparing to ambient aerosol observations at Finokalia monitoring station (Fig. 5e), the model seems to underestimate the observations of TFe with the largest differences calculated for January-February, May and July-September. These are the periods of the year that Finokalia station can be occasionally affected by strong dust outbreaks from Africa
(Kalivitis et al., 2007) that are better represented in the observations than in the model results due to their episodic character. All evaluations (see Supplement Table S3) are based on statistical parameters of correlation coefficient $(R$; Eq. $\mathrm{S} 1)$, normalized mean bias (NMB; Eq. S2), root mean square error (RMSE; Eq. S3), and normalized mean error (NME; Eq. S3).

\subsection{Iron deposition}

TM4-ECPL calculates that $\sim 37 \mathrm{Tg}-\mathrm{Fe} \mathrm{yr}^{-1}$ of TFe are deposited to the Earth's surface (Fig. 6a). The highest annual deposition fluxes of TFe of $\sim 100 \mathrm{ng}-\mathrm{Fe} \mathrm{m}^{-2} \mathrm{~s}^{-1}$ (i.e. $\sim 3.2 \mathrm{~g}-\mathrm{Fe} \mathrm{m}^{-2} \mathrm{yr}^{-1}$ ) are calculated to occur over the Sahara and Gobi deserts. Significant deposition fluxes up to $\sim 10 \mathrm{ng}-$ $\mathrm{Fe} \mathrm{m}{ }^{-2} \mathrm{~s}^{-1}$ are also calculated at the outflow from these 

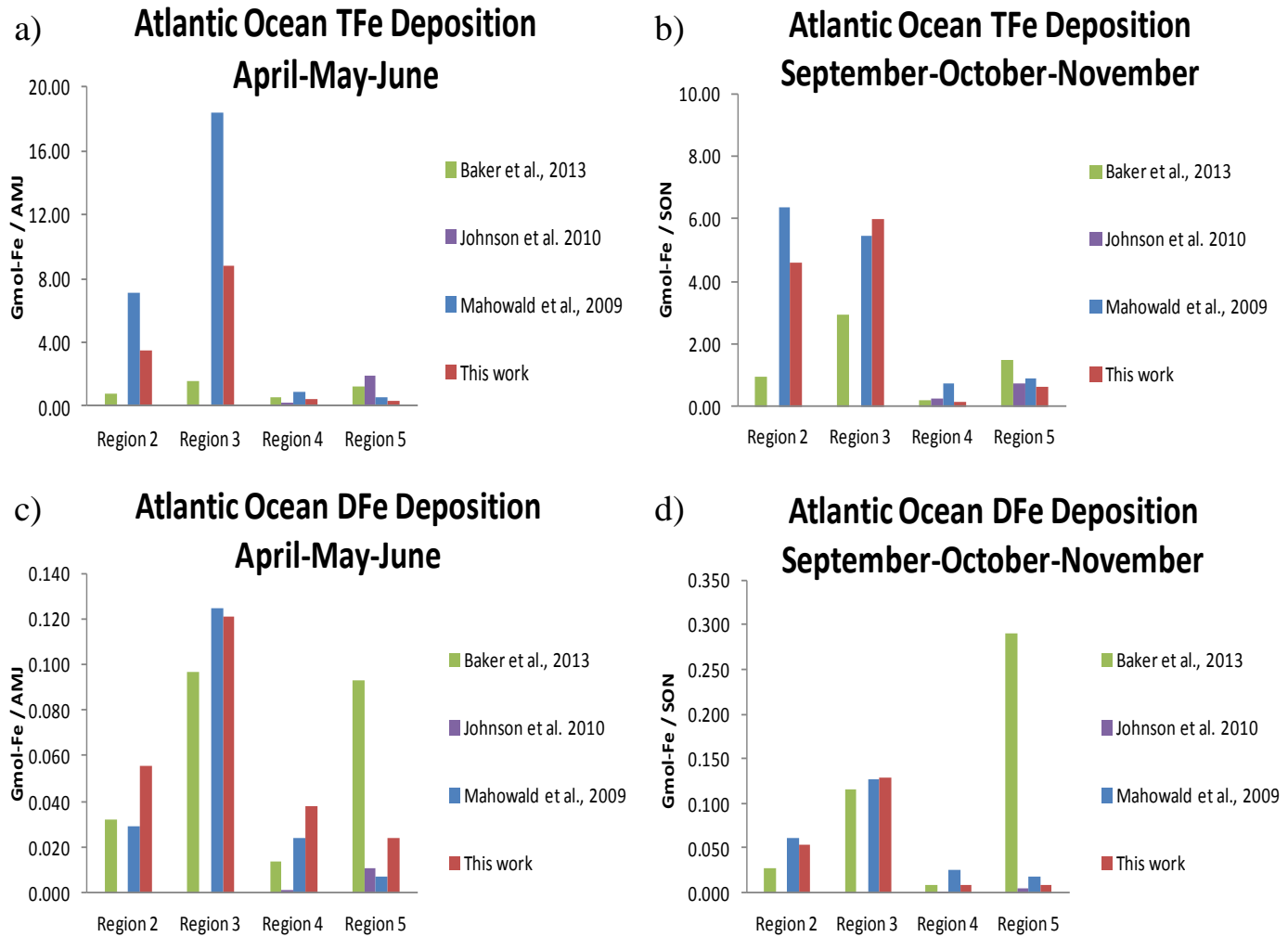

Figure 7. Comparison of total Fe (TFe) and dissolved-Fe (DFe) input estimates to four Atlantic Ocean regions during the April-May-June (AMJ; a, c) and September-October-November (SON; b, d) periods (in Gmol-Fe), as compiled by Baker et al. (2013).

source regions over the Atlantic and Pacific oceans. The computed global DFe deposition is $\sim 0.496 \mathrm{Tg}^{-} \mathrm{Fe}_{\mathrm{yr}}{ }^{-1}$ of which $\sim 0.191 \mathrm{Tg}-\mathrm{Fe} \mathrm{yr}^{-1}$ is deposited over the ocean (Fig. 6b). This oceanic DFe deposition estimate is lower than an earlier reported DFe deposition flux to the ocean of $0.26 \mathrm{Tg}^{-\mathrm{Fe}_{\mathrm{yr}}}{ }^{-1}$ (Johnson and Meskhidze, 2013). However, that study used dust emissions of $\sim 1900 \mathrm{Tg} \mathrm{yr}^{-1}$, about $60 \%$ larger than the dust sources in the present study $\left(\sim 1091 \mathrm{Tg} \mathrm{yr}^{-1}\right.$ for the year 2008). In addition, at least $50 \%$ uncertainty was found to be associated with the applied horizontal resolution of the model in the calculated deposition fluxes, with higher fluxes calculated by the higher model resolution.

Figures $6 \mathrm{c}-\mathrm{f}$ present the seasonal variability of DFe deposition as calculated by TM4-ECPL (in parenthesis the deposition fluxes over the oceans are also provided). The maximum global seasonal DFe deposition flux of $\sim 0.132 \mathrm{Tg}$ Fe season ${ }^{-1}$ is calculated to occur during JJA (JuneJuly-August; Fig. 6e), followed by fluxes of $\sim 0.128 \mathrm{Tg}$ $\mathrm{Fe}$ season $^{-1}$ during DJF (December-January-February; Fig. $6 c$ ) and $\sim 0.127 \mathrm{Tg}-\mathrm{Fe}$ season $^{-1}$ during MAM (MarchApril-May; Fig. 6d). The enhanced photochemistry during summertime over the Northern Hemisphere increases the atmospheric acidity due to $\mathrm{NO}_{x}$ and $\mathrm{SO}_{x}$ oxidation, and thus enhances proton-dissolution of mineral dust. However, combustion emissions from biomass burning and oil combustion of anthropogenic origin also contribute significantly to the DFe tropospheric concentrations. Moreover, OXL aqueousphase formation and therefore organic ligand-promoted $\mathrm{Fe}$ dissolution is favoured due to the high biogenic NMVOC emissions during the warm season (Myriokefalitakis et al., 2011). On the contrary, during SON (September-OctoberNovember; Fig. 6f) the model calculates lower DFe deposition fluxes, of $\sim 0.109 \mathrm{Tg}-\mathrm{Fe}$ season $^{-1}$, due to the weaker photochemical activity and therefore the lower $\mathrm{Fe}$ dissolution fluxes both from proton- and organic ligand-promoted dissolution. Note, also, that most dust and TFe emissions occur in the mid-latitudes of the Northern Hemisphere where the majority of anthropogenic emissions of acidity precursors also occur (Fig. S1).

\subsection{Model iron deposition evaluation}

In Fig. 7, TM4-ECPL deposition fluxes of TFe and $\mathrm{DFe}$ (in this work) are compared to the estimates over four Atlantic Ocean regions (Fig. S7a-d) based on the observations of Baker et al. (2013) as well as the deposition fields from the modelling studies of Mahowald et al. (2009) and Johnson et al. (2010) as compiled and presented by Baker et al. (2013). Both of these modelling studies assumed a constant $\mathrm{Fe}$ content of $3.5 \%$ in dust and a proton-promoted $\mathrm{Fe}$ dissolution. DFe deposition fluxes have been calculated for four 
a)


c)

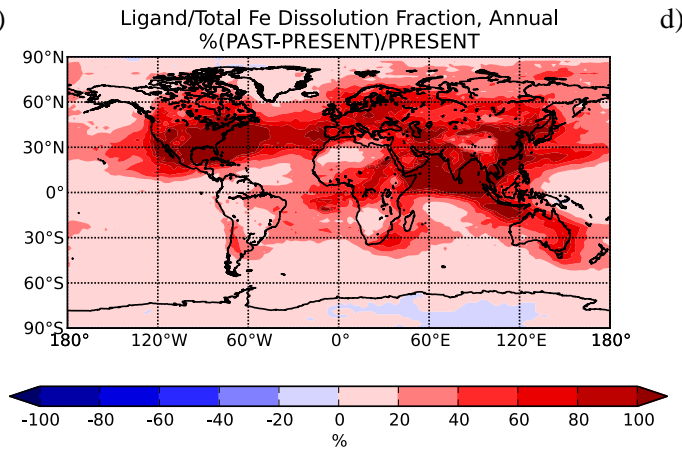

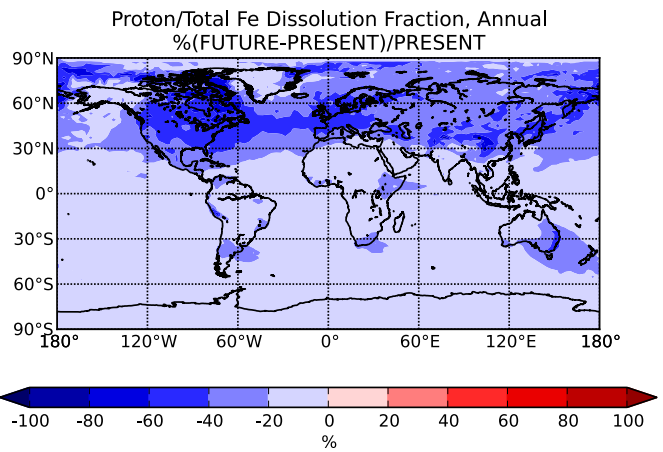

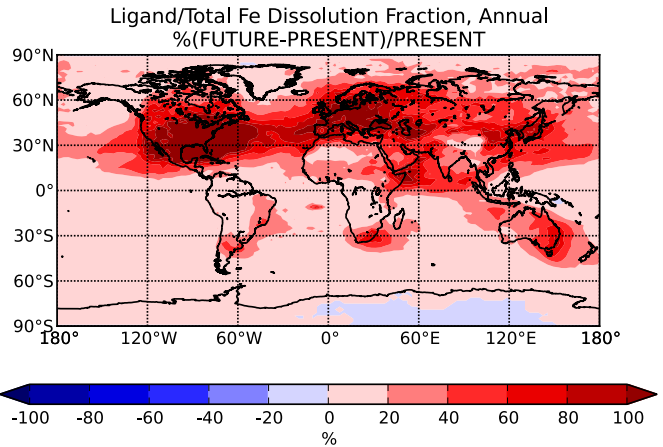

Figure 8. The percentage differences of PAST $(\mathbf{a}, \mathbf{c}, \mathbf{e})$ and FUTURE $(\mathbf{b}, \mathbf{d}, \mathbf{f})$ simulations from the PRESENT simulation for $(\mathbf{a}, \mathbf{b})$ protonpromoted/total mineral-Fe dissolution fraction and $(\mathbf{c}, \mathbf{d})$ ligand-promoted/total mineral-Fe dissolution fraction.

regions, as described in Baker et al. (2013), with Region 2 corresponding to North Atlantic dry regions, Region 3 corresponding to intertropical convergence zone (ITCZ), Region 4 to South Atlantic dry regions and Region 5 to South Atlantic storm rainfall (Fig. S7a-d).

In the South Atlantic (Region 4) during AMJ (AprilMay-June) TM4-ECPL calculations of TFe deposition show a broad agreement with the measurements and also agree with the other modelling studies, when taking the large uncertainty associated with these estimates into account. On the other hand, the model overestimates the measurements of TFe in Region 2 and Region 3 during AMJ similarly to the modelling study by Mahowald et al. (2009). These regions are both strongly affected by Sahara dust outflow; thus the model overestimates TFe observations by Baker et al. (2013), while DFe observations are much better captured by the model. This could be due to a longer lifetime of TFe in the model than in the atmosphere, resulting from smaller size distributions of TFe in the model than in reality. During SON (Fig. 7b), TM4-ECPL overestimates the measured values from Baker et al. (2013) similarly to the modelling study by Mahowald et al. (2009). For Region 4 during SON, the model agrees well with the Baker et al. (2013) estimates and calculates TFe deposition fluxes, which were lower compared to Mahowald et al. (2009) but very close to the estimation by Johnson et al. (2010). Overall, TM4-ECPL model overestimates the observed DFe deposition over Regions 2, 3 and 4 during both studied periods, while it underestimates
DFe deposition over Region 5 similarly to other model estimates (Fig. 7c, d).

\section{Sensitivity of dissolved iron to air-pollutants}

The response of mineral-Fe dissolution to the changes in emissions is assessed here by comparing simulations performed using anthropogenic and biomass burning past and future emissions (see Sect. 2). Atmospheric acidity strongly depends on $\mathrm{SO}_{x}$ and $\mathrm{NO}_{x}$ anthropogenic emissions, and $\mathrm{Fe}$ solubility is impacted by atmospheric acidity as discussed above. Mineral dissolution is therefore expected to be significantly affected by anthropogenic emissions. Iron anthropogenic and biomass-burning emissions also vary, as shown in Table 1 and explained in Sect. 2.3. Note, however, that meteorology, dust emissions and biogenic NMVOC emissions (and thus OXL precursors from biogenic sources) are kept constant for both PAST and FUTURE simulations, corresponding to the year 2008 (i.e. PRESENT simulation). Thus, the computed changes for species that regulate the mineralFe proton and ligand dissolution (e.g. $\mathrm{SO}_{4}^{2-}, \mathrm{NH}_{4}^{+}, \mathrm{NO}_{3}^{-}$and OXL), as presented in Fig. S8, are due to the respective anthropogenic and biomass-burning emission differences between PAST, PRESENT and FUTURE simulations. 


\subsection{Past and future changes in iron dissolution}

For the PAST simulation, the anthropogenic emissions (e.g. $\mathrm{NO}_{x}, \mathrm{NH}_{x}$ and $\mathrm{SO}_{x}$ ) are a factor of 5-10 lower than presentday emissions (Lamarque et al., 2010). Thus, compared to the present day, the model calculates significant changes in the aerosol-phase $\mathrm{pH}$ in the PAST simulation with less acidic (aerosol and cloud) $\mathrm{pH}$ over the surface Northern Hemisphere oceans but a more acidic $\mathrm{pH}$ over Europe due to extensive coal combustion in 1850 (Fig. S2e, g, i). The FUTURE simulation projects, in general, a less acidic aerosol $\mathrm{pH}$ (Fig. S2f, h, j) when compared to the PRESENT simulation, owing to lower $\mathrm{NO}_{x}$ and $\mathrm{SO}_{x}$ emissions. Indeed, for the FUTURE simulation, anthropogenic emissions for most of the continental areas are projected to be lower than the present day and projected to almost return to pre-1980 levels due to air quality regulations (Lamarque et al., 2013).

Past and future changes of the atmospheric acidity (Fig. S2) have a significant effect on mineral-Fe dissolution (Fig. 8a and b, respectively). For the PAST simulation, the model calculates about $80 \%$ lower proton-promoted mineral-Fe dissolution $\left(\sim 0.025 \mathrm{Tg}^{-F e ~} \mathrm{yr}^{-1}\right)$ compared to the PRESENT simulation $\left(\sim 0.137 \mathrm{yr}^{-1}\right)$. As far as the FUTURE simulation is concerned, proton-promoted mineral-Fe dissolution $\left(\sim 0.036 \mathrm{Tg}-\mathrm{Fe} \mathrm{yr}^{-1}\right)$ is also projected to be about 3 times lower than at present. In contrast to these changes due to atmospheric acidity, a higher contribution of organic ligand to the total mineral-Fe dissolution is computed; for the PAST and FUTURE simulations, the model calculates higher global-scale organic ligand-promoted mineral-Fe dissolution ( $\sim 0.040$ and $\sim 0.045 \mathrm{Tg}-\mathrm{Fe} \mathrm{yr}^{-1}$, respectively) compared to the PRESENT $\left(\sim 0.038 \mathrm{yr}^{-1}\right)$. Thus, the contribution of the organic ligand-promoted mineral-Fe dissolution process to the total dissolution flux is calculated to show an inverse pattern compared to the proton-promoted one (Fig. 8c, d). Differences in the $\mathrm{pH}$ of atmospheric (aerosol and cloud) water and oxidant levels can significantly affect OXL aqueousphase chemical production (Myriokefalitakis et al., 2011). According to TM4-ECPL calculations, the increase in OXL levels enhances the organic ligand-promoted mineral-Fe dissolution in remote oceanic regions with very low dust load. However, dust load over the remote oceans could increase if dust outbreaks become more important in the future (Goudie, 2009). One other aspect of the organic ligand-promoted mineral-Fe dissolution is also the effect on the speciation of dissolved and bioavailable Fe. According to the chemical scheme used in this work, the production of $\mathrm{Fe}(\mathrm{II})$ oxalato complexes significantly increases the ferrous content in the $\mathrm{DFe}$, in contrast to the proton-promoted mineral-Fe dissolution where $\mathrm{Fe}(\mathrm{III})$ complexes dominate total DFe production. Indeed, when only the proton-promoted Fe dissolution is considered in our model, the ferrous complexes are produced during the day, when the $\mathrm{Fe}(\mathrm{III})$ is converted into $\mathrm{Fe}(\mathrm{II})$ as a result of the Fe(III) photolysis (e.g. Deguillaume et al., 2004). However, when the organic ligand Fe dissolu- tion is taken into account, the Fe(II) is increased, since there is production of ferrous complexes even under dark conditions. This may also explain the observed high Fe(II) content compared to $\mathrm{Fe}$ (III) in the $\mathrm{DFe}$ in precipitation over the Mediterranean (Theodosi et al., 2010). However, our model calculates much lower Fe(II) content in DFe (Fig. 4c) compared to that study, indicating a model underestimate of the $\mathrm{Fe}(\mathrm{II})$ source, potentially associated with the organic ligandpromoted contribution to DFe. TM4-ECPL calculates that the decrease in the atmospheric acidity both in the PAST and in the FUTURE compared to the PRESENT simulations increases the importance of organic ligand mineral-Fe dissolution and thus leads to a significant enhancement of the Fe(II) surface concentrations and thus its content in DFe (Fig. S9a, b) and a simultaneous reduction of Fe(III) (Fig. S9c, d).

\subsection{Past and future changes in iron deposition}

The model calculates a DFe deposition flux of $\sim 0.213 \mathrm{Tg}$ -

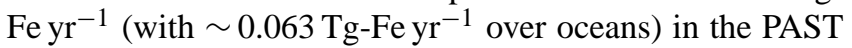
that is about half (to one-third over the oceans) (Fig. S9e, negative differences) compared to PRESENT $(\sim 0.496$ with $\sim 0.191 \mathrm{Tg}^{-F e ~} \mathrm{yr}^{-1}$ over oceans). On the other hand, FUTURE DFe deposition is calculated to be $\sim 0.369 \mathrm{Tg}-$ $\mathrm{Fe} \mathrm{yr}^{-1}$ (with $\sim 0.136 \mathrm{Tg}^{-\mathrm{Fe} \mathrm{yr}^{-1}}$ over oceans) which is about $25 \%$ lower than the simulated global PRESENT deposition (Fig. S9f). This can be explained by lower amounts of combustion DFe-containing aerosols simulated to be emitted in the PAST $\left(\sim 0.011 \mathrm{Tg}^{-} \mathrm{Fe}_{\mathrm{yr}}{ }^{-1}\right.$ from fossil fuel combustion and $\sim 0.013 \mathrm{Tg}^{-} \mathrm{Fe}_{\mathrm{yr}}{ }^{-1}$ from biomass-burning aerosols) compared to the PRESENT simulation $\left(\sim 0.070 \mathrm{Tg}-\mathrm{Fe} \mathrm{yr}^{-1}\right.$ from fossil fuel combustion and $\sim 0.127 \mathrm{Tg}_{-} \mathrm{Fe}_{\mathrm{r}^{-1}}$ from biomass-burning aerosols), as well as in the FUTURE ( $\sim 0.013 \mathrm{Tg}^{-} \mathrm{Fe}_{\mathrm{yr}}{ }^{-1}$ from fossil fuel combustion) compared to the PRESENT simulation. However, higher emissions of biomass-burning Fe-containing aerosols are projected for the FUTURE $\left(\sim 0.155 \mathrm{Tg}_{-} \mathrm{Fe} \mathrm{yr}^{-1}\right)$ (see also Table 1 ) that counteract the projected lower $\mathrm{Fe}$ emissions contained in fossil fuel aerosols and the weaker mineral-Fe dissolution for the FUTURE simulation. The weaker acidification of mineral dust in the past and future, compared to the PRESENT atmosphere (Fig. S7e, g, i and f, h, j) can also be seen in $\mathrm{SO}_{4}^{2-}$ and $\mathrm{NO}_{3}^{-}$surface concentrations, by the negative changes from the present day, shown in Fig. S8a, c and b, and d.

\subsection{Biogeochemical implications}

The determination of iron solubility is important to understand the carbon biogeochemical cycle. Okin et al. (2011) have shown that in HNLC areas, atmospheric deposition of Fe to the surface ocean could account for about $50 \%$ of carbon fixation, although they pointed to the large uncertainties in the speciation and solubility of deposited Fe that are associated with these estimates. Thus, the impact of Fe on ocean productivity, and subsequently on Earth's climate sys- 
a)

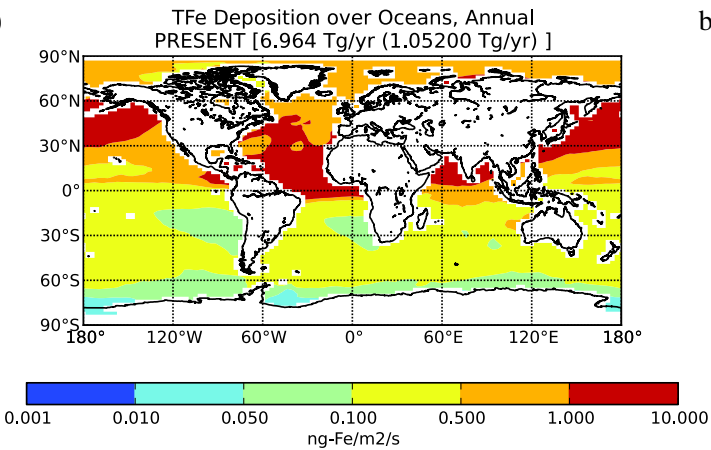

c)

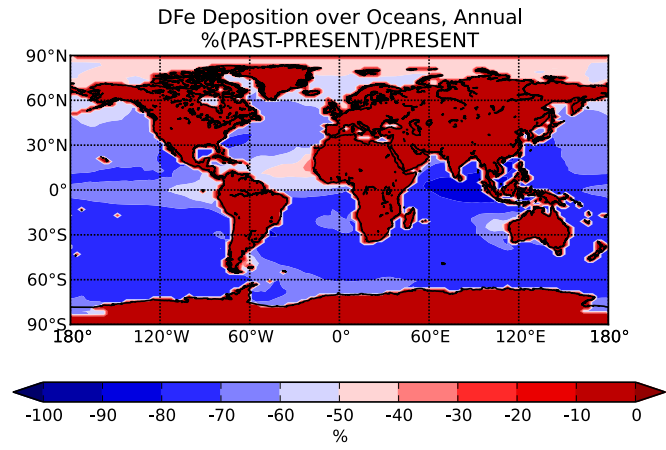

b)

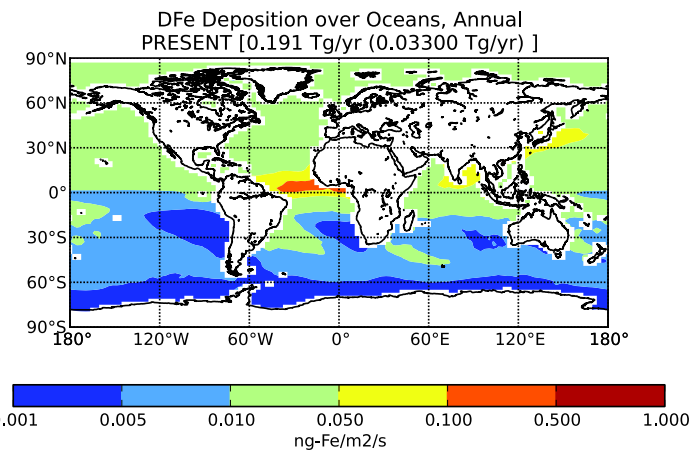

d)

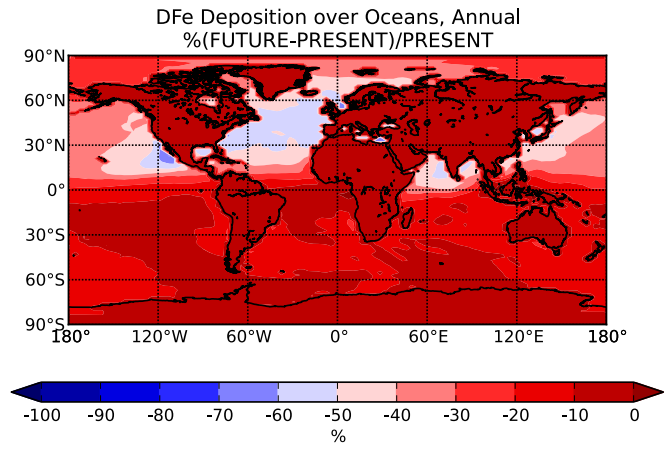

Figure 9. Calculated present annual deposition over oceans (in ng-Fe $\mathrm{m}^{-2} \mathrm{~s}^{-1}$; in brackets (parentheses) the amounts of Fe deposition over oceans (only over HNLC regions are provided)) for (a) TFe and (b) DFe, and the percentage (\%) differences in DFe deposition of (c) PAST and (d) FUTURE simulations from the PRESENT simulation.

tem, is expected to be most important in HNLC areas such as the Southern Ocean (Boyd et al., 2000). However, because the DFe deposited from the atmosphere to the surface water follows the water flow inside the ocean, atmospheric deposition impact is expected to be geographically extended compared to the surfaces where this deposition occurs and can be only evaluated by an ocean biogeochemical model. For the characterization of HNLC oceanic regions in this study, the annual mean global $\mathrm{NO}_{3}^{-}$surface water concentrations from the LEVITUS94 World Ocean Atlas (http: //iridl.ldeo.columbia.edu/SOURCES/.LEVITUS94/) and the monthly chlorophyll $a$ (Chl $a$ ) concentrations MODIS retrievals taken into account in the model (Myriokefalitakis et al., 2010) for the year 2008 are used. The model grid boxes corresponding to HNLC waters (Fig. S7e) are defined here based on the co-occurrence of surface seawater $\mathrm{NO}_{3}^{-}$concentrations of $>4 \mu \mathrm{M}$ (Duce et al., 2008) and Chl $a$ concentrations of $<0.1 \mathrm{mg} \mathrm{m}^{-3}$ (Boyd et al., 2007).

The deposition fluxes of TFe and DFe over oceans are presented in Fig. 9a and b, respectively. The model calculates that $\sim 1.052 \mathrm{Tg}-\mathrm{Fe} \mathrm{yr}^{-1}$ of $\mathrm{TFe}$ are deposited over the HNLC ocean with the maximum deposition fluxes calculated over the North Pacific Ocean $\left(\sim 5-10 \mathrm{ng}-\mathrm{Fe} \mathrm{m}^{-2} \mathrm{~s}^{-1}\right)$ and the lowest over the Southern Ocean $(\sim 0.05-0.5 \mathrm{ng}$ $\mathrm{Fe} \mathrm{m}^{-2} \mathrm{~s}^{-1}$ ). The same pattern is also calculated for the DFe deposition, with maximum $\mathrm{DFe}$ deposition fluxes over the equatorial Atlantic Ocean $\left(\sim 0.5 \mathrm{ng}-\mathrm{Fe} \mathrm{m}^{-2} \mathrm{~s}^{-1}\right)$, relatively high deposition fluxes over the North Pacific Ocean $(\sim 0.01-$ $0.05 \mathrm{ng}-\mathrm{Fe} \mathrm{m}^{-2} \mathrm{~s}^{-1}$ ) and lower over the Southern Ocean (up to $\sim 0.005 \mathrm{ng}-\mathrm{Fe} \mathrm{m}^{-2} \mathrm{~s}^{-1}$ ). TM4-ECPL calculates a deposition flux of $\sim 0.033 \mathrm{Tg}-\mathrm{Fe} \mathrm{yr}^{-1}$ of DFe over the HNLC waters which represents $\sim 17 \%$ of the total oceanic DFe deposition flux and $\sim 7 \%$ of the global one.

The percentage differences of calculated PRESENT DFe deposition fluxes over oceans from the PAST and FUTURE simulations are depicted in Fig. 9c and d, respectively. The model in general calculates for both PAST and FUTURE simulations lower DFe deposition fluxes over oceans. DFe deposition fluxes are calculated to be $\sim 80 \%$ higher in the PRESENT than in the PAST simulation (Fig. 9c), which can be attributed both to the increase of (i) mineral-Fe dissolution (almost 3-fold) and (ii) primary DFe emission (from both fossil fuel combustion (6-fold) and biomass-burning sources (almost an order of magnitude)). Furthermore, based on emission projections following air quality legislation, decreases of about $30-60 \%$ in DFe deposition are calculated for the FUTURE simulation over the North Pacific and Atlantic oceans, the Arabian Sea, the Bay of Bengal and the eastern Mediterranean Sea and lower reductions (less than $20 \%$ ) over the remote tropical Pacific and Atlantic oceans and the Southern Ocean. These smaller changes from the PRESENT simulation calculated for the FUTURE (about a $45 \%$ reduction globally) than for the PAST (almost a 3-fold change globally) are attributed to the projected increase of $\mathrm{Fe}$ 
biomass-burning emissions (about $20 \%$ ) that partially counterbalance the more than 5-fold reduction in anthropogenic emissions of Fe. Overall, these sensitivity PAST-FUTURE simulations clearly support that changes in (i) atmospheric acidity and (ii) Fe combustion sources, both driven by anthropogenic pollutant emissions, affect DFe deposition over the oceans significantly, and therefore they have the potential to also perturb open-ocean phytoplankton growth and thus the carbon biogeochemical cycling.

\section{Conclusions}

Primary Fe emissions from dust and combustion sources (fossil fuel and biomass burning) of TFe and DFe, as well as the atmospheric processing by proton- and organic ligandpromoted mineral-Fe dissolution together with aqueousphase photochemical reactions between oxidation states of Fe (III/II), are taken into account in the state-of-the-art chemistry transport model TM4-ECPL. The model calculates, for present-day conditions, an atmospheric Fe dissolution flux of $\sim 0.175 \mathrm{Tg}-\mathrm{Fe} \mathrm{yr}^{-1}$ of which $\sim 22 \%$ is attributed to the impact of organic ligands on the Fe cycle. The atmospheric burden of DFe is calculated to be $\sim 0.024 \mathrm{Tg}-\mathrm{Fe}$ and the dissolved-Fe annual deposition flux over the oceans to be $\sim 0.119 \mathrm{Tg}_{-} \mathrm{Fe} \mathrm{yr}^{-1}$. SFe (global mean of about $2.8 \%$ ) is calculated to vary spatially with minima over the dust sources ( $\sim 1 \%)$. This global mean solubility of Fe, originates from dust $(1.3 \%)$, biomass-burning aerosols $(1.3 \%)$ and fossil fuel combustion $(0.3 \%)$. Note that these model estimates are associated with large uncertainties in the kinetics of Fe dissolution as well as the primary total and dissolved-Fe emissions. As earlier explained, model results depend on model resolution but more importantly depend on assumptions made in the model, such as neglecting any organic ligand dissolution of $\mathrm{Fe}$ in aerosol water and treating biomassburning and fossil fuel-burning DFe as primary.

Sensitivity simulations show that increases in anthropogenic and biomass burning-emissions since 1850 resulted in both enhanced $\mathrm{Fe}$ combustion emissions and a more acidic environment and thus more than double DFe deposition $\left(\sim 0.213 \mathrm{Tg}^{-F e} \mathrm{yr}^{-1}\right.$ in the year 1850 against $\sim 0.496 \mathrm{Tg}-$ $\mathrm{Fe} \mathrm{rr}^{-1}$ in the present day). Air-quality regulations are projected to decrease anthropogenic emissions and thus atmospheric acidity in 2100. Our model results show a 5fold decrease in Fe emissions from anthropogenic combustion sources $\left(\sim 0.013 \mathrm{Tg}^{-\mathrm{Fe} \mathrm{yr}^{-1}}\right.$ in the year 2100 against $\sim 0.070 \mathrm{Tg}-\mathrm{Fe} \mathrm{yr}^{-1}$ in the present day), and about $45 \%$ reduction in mineral-Fe dissolution $\left(\sim 0.078 \mathrm{Tg}^{-F e} \mathrm{yr}^{-1}\right)$ compared to the present day $\left(\sim 0.175 \mathrm{Tg}_{-} \mathrm{Fe} \mathrm{yr}^{-1}\right)$, while DFe biomass-burning emissions are enhanced by $20 \%$ $\left(\sim 0.155 \mathrm{Tg}^{-F e} \mathrm{yr}^{-1}\right.$ in the year 2100 against $\sim 0.127 \mathrm{Tg}-$

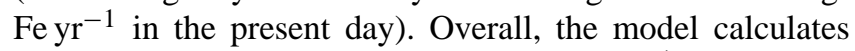
a global DFe deposition of $\sim 0.369 \mathrm{Tg}-\mathrm{Fe}_{\mathrm{yr}}{ }^{-1}$ for the year 2100 that is $\sim 25 \%$ lower than the present-day deposition.
Focusing on oceanic regions, an increase in DFe deposition of $\sim 3$ times is calculated for the last 150 years $\left(0.063 \mathrm{Tg}-\mathrm{Fe} \mathrm{yr}^{-1}\right.$ in the year 1850 against $\sim 0.191 \mathrm{Tg}-$ $\mathrm{Fe}_{\mathrm{yr}}^{-1}$ in the present day) but a decrease of $\sim 30 \%$ over HNLC oceans is projected for the future $\left(0.024 \mathrm{Tg}_{-} \mathrm{Fe} \mathrm{yr}^{-1}\right.$ in the year 2100 against $\sim 0.033 \mathrm{Tg}_{-} \mathrm{Fe} \mathrm{yr}^{-1}$ in the present day). In view of the importance of $\mathrm{Fe}$ as a micronutrient for marine ecosystems, the calculated changes in Fe-containing aerosol solubility due to air-quality changes, indicate the necessity of the implementation of comprehensive mineral-Fe dissolution processes as well as Fe combustion emissions in coupled climate-biogeochemistry models to account for feedbacks between climate and biogeochemical cycles.

\section{The Supplement related to this article is available online at doi:10.5194/bg-12-3973-2015-supplement.}

Acknowledgements. This research has been co-financed by the European Union (European Social Fund - ESF) and Greek national funds through the Operational Program "Education and Lifelong Learning" of the National Strategic Reference Framework (NSRF) Research Funding Program: ARISTEIA - PANOPLY (Pollution Alters Natural aerosol composition: implications for Ocean Productivity, cLimate and air qualitY) grant. We would like to thank Z. Shi and S. Nickovic for fruitful discussions and the two anonymous reviewers for careful reading of the manuscript and useful comments.

Edited by: L. Bopp

\section{References}

Baker, A. R., Adams, C., Bell, T. G., Jickells, T. D., and Ganzeveld, L.: Estimation of atmospheric nutrient inputs to the Atlantic Ocean from $50^{\circ} \mathrm{N}$ to $50^{\circ} \mathrm{S}$ based on large-scale field sampling: Iron and other dust-associated elements, Global Biogeochem. Cy., 27, 755-767, 2013.

Bonneville, S., Vancappellen, P., and Behrends, T.: Microbial reduction of iron(III) oxyhydroxides: effects of mineral solubility and availability, Chem. Geol., 212, 255-268, 2004.

Boyd, P. W., Watson, A. J., Law, C. S., Abraham, E. R., Trull, T., Murdoch, R., Bakker, D. C., Bowie, A. R., Buesseler, K. O., Chang, H., Charette, M., Croot, P., Downing, K., Frew, R., Gall, M., Hadfield, M., Hall, J., Harvey, M., Jameson, G., LaRoche, J., Liddicoat, M., Ling, R., Maldonado, M. T., McKay, R. M., Nodder, S., Pickmere, S., Pridmore, R., Rintoul, S., Safi, K., Sutton, P., Strzepek, R., Tanneberger, K., Turner, S., Waite, A. and Zeldis, J.: A mesoscale phytoplankton bloom in the polar Southern Ocean stimulated by iron fertilization., Nature, 407, 695702, 2000.

Boyd, P. W., Strzepek R., Takeda S.,Wong, C. S., and McKay, R. M.: The evolution and termination of an iron-induced mesoscale bloom in the northeast subarctic Pacific, Limnol. Oceanogr., 50, 1872-1886, 2005. 
Boyd, P. W., Jickells, T., Law, C. S., Blain, S., Boyle, E. A., Buesseler, K. O., Coale, K. H., Cullen, J. J., de Baar, H. J. W., Follows, M., Harvey, M., Lancelot, C., Levasseur, M., Owens, N. P. J., Pollard, R., Rivkin, R. B., Sarmiento, J., Schoemann, V., Smetacek, V., Takeda, S., Tsuda, A., Turner, S., and Watson A. J.: Mesoscale Iron Enrichment Experiments 1993-2005: Synthesis and Future Directions, Science, 315, 5812, doi:10.1126/science.1131669, 2007.

Carlton, A. G., Turpin, B. J., Altieri, K. E., Seitzinger, S., Reff, A., Lim, H.-J., and Ervens, B.: Atmospheric oxalic acid and SOA production from glyoxal: Results of aqueous photooxidation experiments, Atmos. Environ., 41, 7588-7602, 2007.

Chen, H. and Grassian, V. H.: Iron dissolution of dust source materials during simulated acidic processing: the effect of sulfuric, acetic, and oxalic acids., Environ. Sci. Technol., 47, 10312-21, 2013.

Daskalakis, N., Myriokefalitakis, S., and Kanakidou, M.: Sensitivity of tropospheric loads and lifetimes of short lived pollutants to fire emissions, Atmos. Chem. Phys., 15, 3543-3563, doi:10.5194/acp-15-3543-2015, 2015

Dee, D. P., Uppala, S. M., Simmons, A. J., Berrisford, P., Poli, P., Kobayashi, S., Andrae, U., Balmaseda, M. A., Balsamo, G., Bauer, P., Bechtold, P., Beljaars, A. C. M., van de Berg, L., Bidlot, J., Bormann, N., Delsol, C., Dragani, R., Fuentes, M., Geer, A. J., Haimberger, L., Healy, S. B., Hersbach, H., Hólm, E. V., Isaksen, L., Kållberg, P., Köhler, M., Matricardi, M., McNally, A. P., Monge-Sanz, B. M., Morcrette, J. J., Park, B. K., Peubey, C., de Rosnay, P., Tavolato, C., Thépaut, J. N., and Vitart, F.: The ERA-Interim reanalysis: configuration and performance of the data assimilation system, Q. J. Roy. Meteor. Soc., 137, 553-597, 2011.

Deguillaume, L., Leriche, M., Monod, A., and Chaumerliac, N.: The role of transition metal ions on $\mathrm{HO}$ x radicals in clouds: a numerical evaluation of its impact on multiphase chemistry, Atmos. Chem. Phys., 4, 95-110, doi:10.5194/acp-4-95-2004, 2004.

Dentener, F., Kinne, S., Bond, T., and Boucher, O.: Emissions of primary aerosol and precursor gases in the years 2000 and 1750 prescribed data-sets for AeroCom, Atmos. Chem. Phys., 6, 43214344, doi:10.5194/acp-6-4321-2006, 2006.

Duce, R., A. LaRoche, J., Altieri, K., Arrigo, K.R., Baker, A. R., Capone, D. G., Cornell, S.,Dentener, F., Galloway, J., Ganeshram, R. S., Geider, R. J., Jickells, T., Kuypers, M. M., Langlois, R., Liss, P. S., Liu, S. M., Middelburg, J. J., Moore, C. M., Nickovic, S., Oschlies, A., Pedersen, T., Prospero, J., Schlitzer, R., Seitzinger, S., Sorensen, L. L., Uematsu, M., Ulloa, O., Voss, M., Ward, B., and Zamora, L.: Impacts of Atmospheric Anthropogenic Nitrogen on the Open Ocean, Science, 320, 5878, doi:10.1126/science.1150369, 2008.

Ervens, B., George, C., Williams, J. E., Buxton, G. V., Salmon, G. A., Bydder, M., Wilkinson, F., Dentener, F., Mirabel, P., Wolke, R., and Herrmann, H: CAPRAM 2.4 (MODAC mechanism): An extended and condensed tropospheric aqueous phase mechanism and its application, J. Geophys. Res., 108, 1-21, 2003.

Falkowski P., Scholes R.J., Boyle E., Canadell J., Canfield, D., Elser, J., Gruber, N., Hibbard, K., Högberg, P., Linder, S., Mackenzie, F. T., Moore III, B., Pedersen, T., Rosenthal, Y., Seitzinger, S., Smetacek, V., and Steffen W.: The Global Carbon Cycle: A Test of Our Knowledge of Earth as a System, Science, 290, 291-296, 2000.
Fan, S.-M.: Impact of air pollution on wet deposition of mineral dust aerosols, Geophys. Res. Lett., 31, L02104, doi:10.1029/2003GL018501, 2004.

Formenti, P., Rajot, J. L., Desboeufs, K., Caquineau, S., Chevaillier, S., Nava, S., Gaudichet, A., Journet, E., Triquet, S., Alfaro, S., Chiari, M., Haywood, J., Coe, H., and Highwood, E.: Regional variability of the composition of mineral dust from western Africa: results from the AMMA SOP0/DABEX and DODO field campaigns, J. Geophys. Res., 113, D00C13, doi:10.1029/2008JD009903, 2008.

Formenti, P., Caquineau, S., Desboeufs, K., Klaver, A., Chevaillier, S., Journet, E., and Rajot, J. L.: Mapping the physicochemical properties of mineral dust in western Africa: mineralogical composition, Atmos. Chem. Phys., 14, 10663-10686, doi:10.5194/acp-14-10663-2014, 2014.

Fountoukis, C. and Nenes, A.: ISORROPIA II: a computationally efficient thermodynamic equilibrium model for $\mathrm{K}^{+}$ $\mathrm{Ca}^{2+}-\mathrm{Mg}^{2+}-\mathrm{NH}_{4}^{+}-\mathrm{Na}^{+}-\mathrm{SO}_{4}^{2-}-\mathrm{NO}_{3}^{-}-\mathrm{Cl}^{-}-\mathrm{H}_{2} \mathrm{O}$ aerosols: Atmos. Chem. Phys., 7, 4639-4659, doi:10.5194/ acp-7-46392007, 2007.

Goudie, S.: Dust storms: Recent developments, J. Environ. Man., 90, 89-94, 2009.

Granier, C., Guenther, A., Lamarque, J., Mieville, A., Muller, J., Olivier, J., Orlando, J., Peters, J., Petron, G., Tyndall, G., and Wallens, S.: POET, a database of surface emissions of ozone pre-cursors, available at: http://www.pole-ether.fr/eccad (last access: December 2015), ECCAD-Ether Database, 2005.Granier, C., Guenther, A., Lamarque, J., Mieville, A., Muller, J., Olivier, J., Orlando, J., Peters, J., Petron, G., Tyndall, G., and Wallens, S.: POET, a database of surface emissions of ozone precursors, available at: http://www.aero.jussieu.fr/projet/ACCENT/POET. php, 2005.

Huneeus, N., Schulz, M., Balkanski, Y., Griesfeller, J., Prospero, J., Kinne, S., Bauer, S., Boucher, O., Chin, M., Dentener, F., Diehl, T., Easter, R., Fillmore, D., Ghan, S., Ginoux, P., Grini, A., Horowitz, L., Koch, D., Krol, M. C., Landing, W., Liu, X., Mahowald, N., Miller, R., Morcrette, J.-J., Myhre, G., Penner, J., Perlwitz, J., Stier, P., Takemura, T., and Zender, C. S.: Global dust model intercomparison in AeroCom phase I, Atmos. Chem. Phys., 11, 7781-7816, doi:10.5194/acp-11-7781-2011, 2011.

Ito, A.: Global modeling study of potentially bioavailable iron input from shipboard aerosol sources to the ocean, Global Biogeochem. Cy., 27, 1-10, 2013.

Ito, A.: Atmospheric Processing of Combustion Aerosols as a Source of Bioavailable Iron, Environ. Sci. Technol. Lett., 2, 7075, doi:10.1021/acs.estlett.5b00007, 2015.

Ito, A. and Feng, Y.: Role of dust alkalinity in acid mobilization of iron, Atmos. Chem. Phys., 10, 9237-9250, doi:10.5194/acp-109237-2010, 2010.

Ito, A. and $\mathrm{Xu}, \mathrm{L} .:$ Response of acid mobilization of iron-containing mineral dust to improvement of air quality projected in the future, Atmos. Chem. Phys., 14, 3441-3459, doi:10.5194/acp-14-34412014, 2014.

Jeuken, A, Veefkind, J.P., Dentener, F., Metzger, S., and Roble Gonzalez, C.: Simulation of the aerosol optical depth over Europe for August 1997 and a comparison with observations, J. Geophys. Res., 106, 28295-28311, 2001.

Jickells, T. D. and Spokes, L. J.: Atmospheric iron inputs to the oceans, in: The Biogeochemistry of Iron in Seawater, edited by: 
Turner, D. R. and Hunter, K., SCOR/IUPAC Series, John Wiley \& Sons, New York, ISBN: 978-0-471-49068-5, 85-121, 2001.

Johnson, M. S. and Meskhidze, N.: Atmospheric dissolved iron deposition to the global oceans: effects of oxalate-promoted $\mathrm{Fe}$ dissolution, photochemical redox cycling, and dust mineralogy, Geosci. Model Dev., 6, 1137-1155, doi:10.5194/gmd-6-11372013, 2013.

Johnson, M. S., Meskhidze, N., Solmon, F., Gasso, S., Chuang, P. Y., Gaiero, D. M., Yantosca, R. M., Wu, S., Wang, Y., and Carouge, C.: Modeling dust and soluble iron deposition to the South Atlantic Ocean, J. Geophys. Res., 115, D15202, doi:10.1029/2009JD013311, 2010.

Kalivitis, N., Gerasopoulos, E., Vrekoussis, M., Kouvarakis, G., Kubilay, N., Hatzianastassiou, N., Vardavas, I., and Mihalopoulos, N.: Dust transport over the Eastern Mediterranean derived from TOMS, AERONET and surface measurements, J. Geophys. Res., 112, D03202, doi:10.1029/2006JD007510, 2007.

Koulouri, E., Saarikoski, S., Theodosi, C., Markaki, Z., Gerasopoulos, E., Kouvarakis, G., Mäkelä, T., Hillamo, R., and Mihalopoulos, N.: Chemical composition and sources of fine and coarse aerosol particles in the Eastern Mediterranean, Atmos. Environ., 42, 6542-6550, 2008.

Kraemer, S. M.: Iron oxide dissolution and solubility in the presence of siderophores, Aquat. Sci.-Res. Acr. Bound., 66, 3-18, 2004.

Lamarque, J.-F., Bond, T. C., Eyring, V., Granier, C., Heil, A., Klimont, Z., Lee, D., Liousse, C., Mieville, A., Owen, B., Schultz, M. G., Shindell, D., Smith, S. J., Stehfest, E., Van Aardenne, J., Cooper, O. R., Kainuma, M., Mahowald, N., McConnell, J. R., Naik, V., Riahi, K., and van Vuuren, D. P.: Historical (1850-2000) gridded anthropogenic and biomass burning emissions of reactive gases and aerosols: methodology and application, Atmos. Chem. Phys., 10, 7017-7039, doi:10.5194/acp10-7017-2010, 2010.

Lamarque, J.-F., Shindell, D. T., Josse, B., Young, P. J., Cionni, I., Eyring, V., Bergmann, D., Cameron-Smith, P., Collins, W. J., Doherty, R., Dalsoren, S., Faluvegi, G., Folberth, G., Ghan, S. J., Horowitz, L. W., Lee, Y. H., MacKenzie, I. A., Nagashima, T., Naik, V., Plummer, D., Righi, M., Rumbold, S. T., Schulz, M., Skeie, R. B., Stevenson, D. S., Strode, S., Sudo, K., Szopa, S., Voulgarakis, A., and Zeng, G.: The Atmospheric Chemistry and Climate Model Intercomparison Project (ACCMIP): overview and description of models, simulations and climate diagnostics, Geosci. Model Dev., 6, 179-206, doi:10.5194/gmd-6-179-2013, 2013

Lanzl, C. A., Baltrusaitis, J., and Cwiertny, D. M.: Dissolution of hematite nanoparticle aggregates: influence of primary particle size, dissolution mechanism, and solution pH., Langmuir, 28, 15797-15808, 2012.

Lasaga, A. C., Soler, J. M., Ganor, J., Burch, T. E., and Nagy, K. L.: Chemical-weathering rate laws and global geochemical cycles, Geochim. Cosmochim. Ac., 58, 2361-2386, 1994.

Lim, Y. B., Tan Y., Perri, M. J., Seitzinger, S. P., and Turpin, B. J.: Aqueous chemistry and its role in secondary organic aerosol (SOA) formation, Atmos. Chem. Phys., 10, 1052110539, doi:10.5194/acp-10-10521-2010, 2010.

Lim, Y. B., Tan, Y., and Turpin, B. J.: Chemical insights, explicit chemistry, and yields of secondary organic aerosol from $\mathrm{OH}$ radical oxidation of methylglyoxal and glyoxal in the aqueous phase,
Atmos. Chem. Phys., 13, 8651-8667, doi:10.5194/acp-13-86512013, 2013.

Lin, G., Sillman, S., Penner, J. E., and Ito, A.: Global modeling of SOA: The use of different mechanisms for aqueous-phase formation, Atmos. Chem. Phys., 14, 5451-5475, doi:10.5194/acp-145451-2014, 2014.

Louis, J.-F.: A parametric model of vertical eddy fluxes in the atmosphere, Bound. Layer Meteorol., 17, 187-202, 1979.

Luo, C., Mahowald, N., Bond, T., Chuang, P. Y., Artaxo, P., Siefert, R., Chen, Y., and Schauer, J.: Combustion iron distribution and deposition, Global Biogeochem. Cy., 22, GB1012, doi:10.1029/2007GB002964, 2008.

Maher, B. A., Prospero, J. M. Mackie, D., Gaiero, D., Hesse, P. P., and Balkanski, Y.: Global connections between aeolian dust, climate and ocean biogeochemistry at the present day and at the last glacial maximum, Earth-Sci. Rev., 99, 61-97, 2010.

Mahowald, N. M., Baker, A. R., Bergametti, G., Brooks, N., Duce, R. A., Jickells T. D., Kubilay N., Prospero, J. M., and Tegen, I.: The atmospheric global dust cycle and iron inputs to the ocean, Global Biogeochem. Cy., 19, GB4025, doi:10.1029/2004GB002402, 2005.

Mahowald, N. M., Engelstaedter, S., Luo, C., Sealy, A., Artaxo, P., Benitez-Nelson, C., Bonnet, S., Chen, Y., Chuang, P. Y., Cohen, D. D., Dulac, F., Herut, B., Johansen, A. M., Kubilay, N., Losno, R., Maenhaut, W., Paytan, A., Prospero, J. M., Shank, L. M., and Siefert, R. L.: Atmospheric Iron deposition: Global distribution, variability and human perturbations, Annu. Rev. Mar. Sci., 1, 245-278, 2009.

Martin, J. H. and Fitzwater S. E.: Iron deficiency limits phytoplankton growth in the north-east Pacific subarctic, Nature, 331, 341343, 1988.

McNeill, V. F., Woo, J. L.. Kim, D. D., Schwier, A. N., Wannell, N. J., Sumner, A. J., and Barakat J. M.: Aqueous-Phase Secondary Organic Aerosol and Organosulfate Formation in Atmospheric Aerosols: A Modeling Study, Environ. Sci. Technol., 46, 80758081, 2012.

Meskhidze, N., Chameides W. L., and Nenes, A.: Dust and pollution: A recipe for enhanced ocean fertilization?, J. Geophys. Res., 110, d03301, doi:10.1029/2004jd005082, 2005.

Moore, J. K. and Doney, S. C.: Iron availability limits the ocean nitrogen inventory stabilizing feedbacks between marine denitrification and nitrogen fixation, Global Biogeochem. Cy., 21, GB2001, doi:10.1029/2006GB002762, 2007.

Myriokefalitakis, S., Vrekoussis, M., Tsigaridis, K., Wittrock, F., Richter, A., Bruhl, C., Volkamer, R., Burrows, J. P., and Kanakidou, M.: The influence of natural and anthropogenic secondary sources on the glyoxal global distribution, Atmos. Chem. Phys., 8, 4965-4981, doi:10.5194/acp-8-4965-2008, 2008.

Myriokefalitakis, S., Vignati, E., Tsigaridis, K., Papadimas, C., Sciare J., Mihalopoulos, N., Facchini, M. C., Rinaldi, M., Dentener, F. J., Ceburnis, D., Hatzianastasiou, N., O'Dowd, C. D., van Weele, M., and Kanakidou, M.: Global modelling of the oceanic source of organic aerosols, Adv. Meteorol., 2010, 939171, 16 pp., doi:10.1155/2010/939171, 2010.

Myriokefalitakis, S., Tsigaridis, K., Mihalopoulos, N., Sciare, J., Nenes, A., Kawamura, K., Segers, A., and Kanakidou, M.: Incloud oxalate formation in the global troposphere: a 3-D modeling study, Atmos. Chem. Phys., 11, 5761-5782, doi:10.5194/acp11-5761-2011, 2011. 
Nenes, A., Krom, M. D., Mihalopoulos, N., Van Cappellen, P., Shi, Z., Bougiatioti, A., Zarmpas, P., and Herut, B.: Atmospheric acidification of mineral aerosols: a source of bioavailable phosphorus for the oceans, Atmos. Chem. Phys., 11, 6265-6272, doi:10.5194/acp-11-6265-2011, 2011.

Nickovic, S., Vukovic, A., Vujadinovic, M., Djurdjevic, V., and Pejanovic, G.: Technical Note: High-resolution mineralogical database of dust-productive soils for atmospheric dust modeling, Atmos. Chem. Phys., 12, 845-855, doi:10.5194/acp-12-8452012, 2012.

Nickovic, S., Vukovic, A., and Vujadinovic, M.: Atmospheric processing of iron carried by mineral dust, Atmos. Chem. Phys., 13, 9169-9181, doi:10.5194/acp-13-9169-2013, 2013.

Oakes, M., Ingall, E. D., Lai, B., Shafer, M. M., Hays, M. D., Liu, Z. G., Russell, A. G., and Weber, R. J.: Iron solubility related to particle sulfur content in source emission and ambient fine particles, Environ. Sci. Technol., 46, 6637-6644, 2012.

Okin, G. S., Baker, A. R., Tegen, I., Mahowald, N. M., Dentener, F. J., Duce, R. A., Galloway, J. N., Hunter, K., Kanakidou, M., Kubilay, N., Prospero, J. M., Sarin, M., Surapipith, V., Uematsu, M., and Zhu, T.: Impacts of atmospheric nutrient deposition on marine productivity: Roles of nitrogen, phosphorus, and iron, Global Biogeochem. Cy., 25, GB2022, doi:10.1029/2010GB003858, 2011.

Olivie, D. J. L., van Velthoven, P. F. J., Beljaars, A. C. M., and Kelder H. M.: Comparison between archived and off - line diagnosed convective mass fluxes in the chemistry transport model TM3, J. Geophys. Res., 109, D11303, doi:10.1029/2003JD004036, 2004.

Paris, R. and Desboeufs, K. V.: Effect of atmospheric organic complexation on iron-bearing dust solubility, Atmos. Chem. Phys., 13, 4895-4905, doi:10.5194/acp-13-4895-2013, 2013.

Paris, R., Desboeufs, K., and Journet, E.: Variability of dust iron solubility in atmospheric waters: Investigation of the role of oxalate organic complexation, Atmos. Environ., 45, 6510-6517, 2011.

Raes, F., Van Dingenen, R., Vignati, E., Wilson, J., Putaud, J.-P., Seinfeld, J. H., and Adams, P.: Formation and cycling of aerosols in the global troposphere, Atmos. Environ., 34, 4215-4240, 2000.

Russell, G. L. and Lerner, J. a.: A New Finite-Differencing Scheme for the Tracer Transport Equation, J. Appl. Meteorol., 20, 14831498, 1981.

Seinfeld, J. H. and Pandis, S. N.: Atmospheric Chemistry and Physics: From Air Pollution to Climate Change, A Wiley Interscience publication, New York, USA, 1998.

Shao, Y., Wyrwoll, K.-H., Chappell, A., Huang, J., Zhaohui, L., McTainsh G.H., Mikami, M., Tanaka, T. Y., Wang, X., and Yoon, S.: Dust cycle: An emerging core theme in Earth system science, Aeol. Res., 2, 181-204, 2011.

Shi, Z., Bonneville, S., Krom, M. D., Carslaw, K. S., Jickells, T. D., Baker, A. R., and Benning, L. G.: Iron dissolution kinetics of mineral dust at low $\mathrm{pH}$ during simulated atmospheric processing, Atmos. Chem. Phys., 11, 995-1007, doi:10.5194/acp11-995-2011, 2011a.

Shi, Z., Krom M., Bonneville, S., Baker, A.R., Bristow, C., Drake, N., Mann, G., Carslaw, K., McQuaid, J.B., Jickells, T., and Benning, L.G.: Influence of chemical weathering and aging of iron oxides on the potential iron solubility of Saharan dust during simulated atmospheric processing, Global Biogeochem. Cy., 25, GB2010, doi:10.1029/2010GB003837, 2011b.
Shi, Z., Krom, M. D., Jickells T. D., Bonneville, S., Carslaw, K. S., Mihalopoulos, N., Baker, A. R., and Benning, L. G.: Impacts on iron solubility in the mineral dust by processes in the source region and the atmosphere: A review, Aeol. Res. 5, 21-42, 2012.

Sholkovitz E. R., Sedwick P. N., Church T. M., Baker A. R., and Powell C. F.: Fractional solubility of aerosol iron: synthesis of a global-scale data set, Geochim. Cosmochim. Acta, 89, 173-189, 2012.

Sindelarova, K., Granier, C., Bouarar, I., Guenther, A., Tilmes, S., Stavrakou, T., Müller, J.-F., Kuhn, U., Stefani, P., and Knorr, W.: Global data set of biogenic VOC emissions calculated by the MEGAN model over the last 30 years, Atmos. Chem. Phys., 14, 9317-9341, doi:10.5194/acp-14-9317-2014, 2014.

Solmon, F., Chuang, P. Y., Meskhidze, N., and Chen, Y.: Acidic processing of mineral dust iron by anthropogenic compounds over the north Pacific Ocean, J. Geophys. Res., 114, D02305, doi:10.1029/2008JD010417, 2009.

Stumm, W. and Morgan, J. J.: Aquatic Chemistry, 3rd edn., J. Wiley-Interscience, New York, 1022 pp., 1996.

Stumm, W. and Sulzberger, B.: The cycling of iron in natural environments: Considerations based on laboratory studies of heterogeneous redox processes, Geochim. Cosmochim. Ac., 56, 32333257, 1992.

Taylor, S. R. and McLennan S. M.: The Continental Crust: Its Composition and Evolution, Blackwell, Malden, Mass, 312 pp., 1985.

Theodosi, C., Markaki, Z., and Mihalopoulos, N.: Iron speciation, solubility and temporal variability in wet and dry deposition in the Eastern Mediterranean, Mar. Chem., 120, 100-107, 2010.

Tiedke, M.: A comprehensive mass flux scheme for cumulus parameterization in large - scale models, Mon. Weather Rev., 117, 1779-1800, 1989.

Tsigaridis, K. and Kanakidou, M.: Global modelling of secondary organic aerosol in the troposphere: a sensitivity analysis, Atmos. Chem. Phys., 3, 1849-1869, doi:10.5194/acp-3-1849-2003, 2003.

Tsigaridis K. and Kanakidou, M.: Secondary organic aerosol importance in the future atmosphere, Atmos. Environ., 41, 4682-4692, 2007.

Tsigaridis, K., Krol, M., Dentener, F. J., Balkanski, Y., Lathièere, J., Metzger, S., Hauglustaine, D. A., and Kanakidou, M.: Change in global aerosol composition since preindustrial times, Atmos. Chem. Phys., 6, 5143-5162, doi:10.5194/acp-6-5143-2006, 2006.

Van Noije, T. P. C., Eskes, H. J., van Weele, M., and van Velthoven, P. F. J.: Implications of the enhanced Brewer-Dobson circulation in European Centre for Medium-Range Weather Forecasts reanalysis ERA-40 for the stratosphere-troposphere exchange of ozone in global chemistry transport models, J. Geophys. Res. D Atmos., 109, 1-13, 2004.

Witt, M., Baker, A. R., and Jickells T. D.: Atmospheric trace metals over the Atlantic and South Indian Oceans: Investigation of metal concentrations and lead isotope ratios in coastal and remote marine aerosols, Atm. Environ., 40, 5435-5451, 2006.

Zhu, X. R., Prospero, J. M., Millero, F. J., and Savoie, D. L.: The photochemical reaction in marine aerosol solution and its impact to iron concentration, J. Geophys. Res., 98, 9039-9047, 1993. 